\title{
Chemical and Sensory Profiling of Monovarietal Extra Virgin Olive Oils from the Italian Marche Region
}

\author{
Deborah Pacetti ${ }^{1}$, Maria Chiara Boarelli ${ }^{2}$, Rita Giovannetti ${ }^{2} \oplus$, Stefano Ferraro ${ }^{2}$, Paolo Conti ${ }^{2} \oplus$, \\ Barbara Alfei ${ }^{3}$, Giovanni Caprioli ${ }^{4}{ }^{\mathbb{D}}$, Massimo Ricciutelli ${ }^{5}$, Gianni Sagratini ${ }^{4}$, \\ Donatella Fedeli ${ }^{4}$, Rosita Gabbianelli ${ }^{4}\left(\mathbb{D}\right.$ and Dennis Fiorini ${ }^{2, *}$ \\ 1 Department of Agricultural, Food, and Environmental Sciences, Polytechnic University of Marche, \\ Via Brecce Bianche, I-60131 Ancona, Italy; d.pacetti@staff.univpm.it \\ 2 School of Science and Technology, Chemistry Division, University of Camerino, V. S. Agostino 1, \\ I-62032 Camerino (Macerata), Italy; mariachiara.boarelli@unicam.it (M.C.B.); \\ rita.giovannetti@unicam.it (R.G.); stefano.ferraro@unicam.it (S.F.); paolo.conti@unicam.it (P.C.) \\ 3 Agri-food Service Agency of Marche Region (ASSAM), Via dell'Industria 1, I-60027 Ancona, Italy; \\ alfei_barbara@assam.marche.it \\ 4 School of Pharmacy, University of Camerino, V. S. Agostino 1, I-62032 Camerino (Macerata), Italy; \\ giovanni.caprioli@unicam.it (G.C.); gianni.sagratini@unicam.it (G.S.); donatella.fedeli@unicam.it (D.F.); \\ rosita.gabbianelli@unicam.it (R.G.) \\ 5 HPLC-MS Laboratory, University of Camerino, V. S. Agostino 1, I-62032 Camerino (Macerata), Italy; \\ massimo.ricciutelli@unicam.it \\ * Correspondence: dennis.fiorini@unicam.it; Tel.: +39-0737-402254
}

Received: 21 March 2020; Accepted: 13 April 2020; Published: 17 April 2020

check for updates

\begin{abstract}
Chemical and sensory peculiarities of monovarietal extra virgin olive oils (MEVOOs) from the cultivars (cvs.) Ascolana tenera (ASC), Coroncina (COR), Mignola (MIG), Piantone di Mogliano (MOG), and Raggia (RAG) from Marche region (Italy) are investigated. Their polar phenolic substances and $\alpha$-tocopherol are analysed through high performance liquid chromatography with different detectors. Volatile substances, fatty acid composition, and squalene are analysed by gas chromatography coupled to mass spectrometry (MS) and to the flame ionization detector, respectively. Total antioxidant activity and sensory analysis were also performed. MOG showed high squalene content (on average $0.88 \pm 0.16 \mathrm{~g} / 100 \mathrm{~g}$ ), high relative amount of $\alpha$-copaene among volatiles, and the highest oleic acid percentage. MIG had high $\alpha$-tocopherol content (on average $350.0 \pm 57.6 \mathrm{mg} \mathrm{kg}^{-1}$ ) and high $\alpha$-farnesene in the volatile fraction. ASC showed the highest sensory quality and the lignan pinoresinol with higher concentration as compared to the other MEVOOs $(p<0.05)$, which resulted in a possible chemical marker for this $\mathrm{cv}$. RAG was characterized by the sensory note of almond, which corresponds to its highest (E)-2-hexenal percentage. Sensory analysis and an antioxidant activity assay performed on a set of industrial extra virgin olive oils purchased in supermarkets, highlighted MEVOOs' superiority from these points of view. Principal component analysis displays the main characteristics of the cvs. investigated.
\end{abstract}

Keywords: Italian monovarietal extra virgin olive oil; chemical profile; sensory analysis; antioxidant activity; Ascolana tenera; Coroncina; Mignola; Piantone di Mogliano; Raggia

\section{Introduction}

Extra virgin olive oil (EVOO) is considered the prince of edible oils due to its chemical composition rich of bioactive beneficial molecules and provides appreciated sensory characteristics [1]. In particular, the strength point of the chemical composition, is that both the major as well as the minor components have characteristics that are ideal in an oil. The saponifiable fraction is very well balanced, where oleic 
acid, which is a monounsaturated fatty acid, is largely the most represented fatty acid, which provides relatively high oxidative stability, even with a low content of saturated fatty acids. The unsaponifiable fraction contains a large number of different bioactive substances, which play a key role for the oil oxidative stability while promoting health effects and the sensory characteristics of the oil [2]. Several are the characteristics that recognize a food as being excellent. Italy is recognized as a leading country in terms of excellent food production, as demonstrated by the numerous cases of frauds often dealing with fake Italian foods [3]. The safeguard of the identity of food products having specific and special characteristics is allowed by the recognition of the chemical peculiarities characterizing high quality and niche products. Monovarietal EVOOs (MEVOOs) are in the foreground among Italian niche food products. The Italian germoplasm numbers over 800 cultivars (cvs.) [4] and the MEVOOs that can be obtained are products reflecting the characteristics of a country beyond the genetics. Furthermore, legislation helps to protect the origin of the products [5], which allows Protected Denominations of Origin (PDO) or Protected Geographical Indication (PGI) [4]. However, a deep knowledge of the chemical, and, thus, nutritional, peculiarities of MEVOOs is still lacking due to a recent growth of market for these excellent products [6]. Their detailed characterization leads to identify their key features and the relation with their quality. However, several cvs. that are spread in specific areas are not yet investigated extensively.

Starting from this premise, this study aims to obtain a chemical and sensorial fingerprint of MEVOOs produced in the Marche region (Italy), from five cvs. (Raggia, Piantone di Mogliano, Ascolana tenera, Mignola, and Coroncina), selected among those more spread on that country and producing appreciated oils, often receiving prizes in regional, national, and sometimes international competitions in which their sensory properties are evaluated [7]. On oils obtained from the same varieties, other studies have been reported in literature. Rotondi et al. [4] reported average fatty acid, total phenol content, and sensory profiles of 16 MEVOOs oils out of the 177 varieties for which these parameters are also reported in the Italian monovarietal oils database [8]. Cecchi and Alfei [9] studied the volatiles profile of 11 different monovarietal oils from the Marche region (Italy) and correlated it with the sensory profile of the oils. Fiori et al. [10] evaluated the effect of malaxation time on the polyphenol content and composition of Ascolana tenera oil and its oxidation stability. The same variety is also investigated in a study [11] where it was introduced in Tunisia together with other varieties. The monovarietal oils produced were compared with that obtained from the autochthonous variety Chetoui by investigating several parameters related to oil quality.

The present study, aiming to characterize the oils from the five cvs. Raggia (RAG), Piantone di Mogliano (MOG), Ascolana tenera (ASC), Mignola (MIG), and Coroncina (COR), applies to a relatively high number of different samples for each cultivar, obtained from different producers and from different areas crops, in each of the two years harvest (2015 and 2016). There were 6-12 oil samples for each year, for each cultivar. Thus, it may allow the attribution of some characteristics specifically to the olive cultivar. In particular, polar phenolic substances, volatile substances, fatty acid composition, tocopherol content, squalene content, antioxidant activity, and sensory properties, have been investigated. To the best of our knowledge, several of these parameters (e.g., squalene, $\alpha$-tocopherol, antioxidant activity), have never been investigated in MEVOOs from these varieties.

Thus, the results of such a study contribute to fill the gap in the knowledge of features affecting nutritional, healthy, and sensory value of these oils and to better understand the relation between quality and chemical composition in EVOOs.

\section{Materials and Methods}

\subsection{Reagents and Standards}

The analytical standards of hydroxytyrosol, tyrosol, vanillic acid, oleuropein, luteolin, and apigenin were purchased from Extrasynthese (Genay, France). p-Coumaric acid, ferulic acid, pinoresinol, syringic acid, $\alpha$-tocopherol, 2,2'-azinobis-(3-ethylbenzothiazoline-6-sulfonate) (ABTS), and Trolox were 
purchased from Sigma-Aldrich (Milan, Italy). High performance liquid chromatography (HPLC) -grade methanol, hexane, and isopropanol (IPA) were purchased from Sigma-Aldrich (Milan, Italy). Water (resistivity above $18 \mathrm{M} \Omega \mathrm{cm}$ ) was obtained from a Milli-Q SP Reagent Water System (Millipore, Bedford, MA, USA). Solvents and solutions were filtered through a $0.45-\mu \mathrm{m}$ polytetrafluoroethylene (PTFE) filter from Supelco (Bellefonte, PA, USA).

\subsection{Sampling}

A total of 79 MEVOOs from the crs. ASC, COR, MIG, MOG, and RAG have been investigated. For each cultivar, several samples were provided by different producers from different areas of Marche region (Italy) for a total of 36 MEVOOs samples from the olive campaign 2015 (6 ASC, 7 COR, 7 MIG, 9 MOG, 7 RAG) and 43 (8 ASC, 7 COR, 8 MIG, 8 MOG, 12 RAG) from the olive campaign 2016. For each sample, two $0.75 \mathrm{~L}$ bottles were provided. One was used for the sensory analysis and another one was used for the chemical analysis. Additionally, a set of 24 industrial EVOOs purchased from local supermarkets were investigated for the sensory profile and for the antioxidant activity. According to their labels, 12 of these were produced in Italy with Italian olives and had a price between 8.29 and 25.8 euro/L and 12 were from EU countries, with a price between 3.78 and 7.49 euro/L. Samples were stored away from light and at $4{ }^{\circ} \mathrm{C}$ until the analysis. Before the analysis, samples were left reaching a temperature of $25^{\circ} \mathrm{C}$ and gently homogenized. For each of the two years of sampling, oils were analysed in the period March-April after their arrival in the laboratory.

\subsection{Fatty Acid Composition}

Fatty acid methyl esters were obtained by reacting $5 \mathrm{mg}$ of the oil dissolved in hexane $(1 \mathrm{~mL})$ with $2 \mathrm{~N}$ potassium hydroxide in methanol $(0.1 \mathrm{~mL})$ in a 4-mL screw capped vial, which was shaken for $2 \mathrm{~min}$ with a vortex device. Then, $1.5 \mathrm{~mL}$ of $0.15 \mathrm{M}$ acetic acid aqueous solution was added to quench the reaction and other $0.5 \mathrm{~mL}$ of hexane to allow a better separation of the two phases. The mixture was vortexed for $30 \mathrm{~s}$ and then centrifuged for $2 \mathrm{~min}$ at $5000 \mathrm{rpm}$. The upper hexane phase was then analysed in a gas chromatograph (GC) coupled with a flame ionization detector (FID). One $\mu \mathrm{L}$ was injected in split mode (ratio 1:30) in the hot split/splitless injector (T $260^{\circ} \mathrm{C}$ ) of a GC-FID (6850 Agilent Technologies, Santa Clara, CA, USA). The carrier gas was hydrogen produced by a generator (PGH2-250 from DBS Analytical Instruments, Vigonza, Italy). The initial gas flow in the column was $3.7 \mathrm{~mL} / \mathrm{min}$. Chromatographic column coating was $50 \%$ cyanopropylphenyl and 50\% polydimethylsiloxane (DB-225-MS, length $30 \mathrm{~m}, 0.25 \mathrm{~mm}$ i.d., $0.25 \mu \mathrm{m}$ film thickness, Agilent Technologies, Santa Clara, CA, USA). The oven temperature program was increased to $220^{\circ} \mathrm{C}$ at a rate of $20^{\circ} \mathrm{C} / \mathrm{min}$, maintained for $5 \mathrm{~min}$, and then increased at $20^{\circ} \mathrm{C} / \mathrm{min}$ to $240{ }^{\circ} \mathrm{C}$. The temperature was held for $1 \mathrm{~min}$, which resulted in a total run time of $19 \mathrm{~min}$. The FID temperature was $250{ }^{\circ} \mathrm{C}$ and air and hydrogen flows were 400 and $40 \mathrm{~mL} / \mathrm{min}$, respectively.

\subsection{Quantification of Olive oil Polar Phenolic Compounds by HPLC-DAD-ESI/MS}

A previously reported procedure [12] was followed to extract and analyse polar phenolic substances. Briefly, $0.5 \mathrm{~g}$ of oil were dissolved in $0.5 \mathrm{~mL}$ of hexane. The internal standard solution was added $(20 \mu \mathrm{L}$ of $100 \mathrm{mg} \mathrm{L}^{-1}$ syringic acid in methanol) and extracted with $4 \times 0.5 \mathrm{~mL}$ of methanol: water $(60: 40, v / v)$. The hydro-alcoholic solutions were collected, washed with $1 \mathrm{~mL}$ of hexane to remove acylglycerols left, evaporated to dryness, and reconstituted with $0.25 \mathrm{~mL}$ of methanol before the analysis.

Analyses were performed using an HPLC Agilent 1100 (Santa Clara, CA, USA) with a diode-array detector (DAD) and a mass spectrometer detector (ion trap G2445D SL) equipped with an electrospray ionization (ESI) source in reported conditions [13]. A Synergi Polar reverse phase $(250 \times 4.6 \mathrm{~mm}$, $4 \mathrm{~m}$ ) analytical column from Phenomenex (Chesire, UK) was used with, as a mobile phase, water (A) and methanol/IPA 90:10 $v / v$ with (B) each containing $0.1 \%$ formic acid, working in the gradient mode at a flow rate of $1 \mathrm{~mL} \mathrm{~min}-1$, and injecting $10 \mu \mathrm{L}$ of sample extract solution. Gradient used was: $0 \mathrm{~min}, 30 \% \mathrm{~B}, 0-40 \mathrm{~min}, 60 \% \mathrm{~B}, 40-50 \mathrm{~min}$ 95\% B. In HPLC-DAD analysis, different wavelengths were 
monitored: $260 \mathrm{~nm}$ for vanillic acid, $280 \mathrm{~nm}$ for hydroxytyrosol, tyrosol, and secoiridoids derivatives, pinoresinol, acetoxypinoresinol, and syringic acid, $310 \mathrm{~nm}$ for $p$-coumaric acid, $325 \mathrm{~nm}$ for ferulic acid, $338 \mathrm{~nm}$ for apigenin, and $350 \mathrm{~nm}$ for luteolin. In HPLC-ESI-MS, the ion source was operated in a negative ionization (NI) mode and a mass analyser in full scan mode. Mass scan was performed in the range $\mathrm{m} / \mathrm{z}$ 70-1100. The main secoiridoid derivatives were quantified using the calibration curve of tyrosol. Acetoxypinoresinol was quantified with the calibration curve of pinoresinol, while all the other phenolics quantified each one with its own calibration curve, as reported in [12].

\subsection{Determination of $\alpha$-Tocopherol}

A $25 \mathrm{mg} / \mathrm{mL}$ solution of the oil sample in hexane was prepared and filtered through a $0.45-\mu \mathrm{m}$ PTFE filter before the analysis by HPLC coupled to a fluorescence detector (HPLC-FLD), performed injecting $10 \mu \mathrm{L}$. The analytical column used was a Hypersil silica column $(200 \times 2.1 \mathrm{~mm}, 5 \mu \mathrm{m}$, from Thermo Fisher Scientific, Waltham, Massachusetts, USA). The mobile phase was hexane with $0.25 \%$ IPA, at a flow rate of $0.5 \mathrm{~mL} \mathrm{~min}{ }^{-1}$. FLD was set with an excitation wavelength of $290 \mathrm{~nm}$ and an emission wavelength of $330 \mathrm{~nm}$. For the quantification, a calibration curve (correlation coefficient $R=0.9992$ ) was built by analyzing seven standard stock solutions of $\alpha$-tocopherol in hexane at concentrations of $0.53-10.6 \mu \mathrm{g} \mathrm{mL}-1$.

\subsection{Volatile Substances}

A $1.5 \mathrm{~g}$ of oil in a screw cap vial with pierceable septum was conditioned at $40{ }^{\circ} \mathrm{C}$ for $10 \mathrm{~min}$ by stirring at $300 \mathrm{rpm}$ with a small magnet. A solid-phase microextraction fibre coated with $50 / 30 \mu \mathrm{m}$ divinylbenzene/carboxen/polydimethylsiloxane (DVB/CAR/PDMS), $1 \mathrm{~cm}$ long, was then exposed to the headspace of the sample for $30 \mathrm{~min}$. Analytes were desorbed in the hot gas chromatograph injector kept at $260^{\circ} \mathrm{C}$ by performing the injection in a splitless mode $(4 \mathrm{~min})$. The instrument used was a GC coupled to a mass spectrometer detector (Agilent 6850 GC-MSD 5973N, Agilent Technologies, Santa Clara, CA, USA). The separation was performed with a capillary column coated with polyethylene glycol (DB-WAX, length $60 \mathrm{~m}$, internal diameter $0.25 \mathrm{~mm}$, film thickness $0.25 \mu \mathrm{m}$, Agilent Technologies, Santa Clara, CA, USA). Carrier gas (helium) flow was $1.2 \mathrm{~mL} \mathrm{~min}^{-1}$, and the oven temperature program was: $40{ }^{\circ} \mathrm{C}$ held for $4 \mathrm{~min}$, then ramped at $2.5^{\circ} \mathrm{C} \mathrm{min}{ }^{-1}$ until $120{ }^{\circ} \mathrm{C}$, and then ramped at $15{ }^{\circ} \mathrm{C}$ $\mathrm{min}^{-1}$ until $250^{\circ} \mathrm{C}$. Then it was held for $3.33 \mathrm{~min}$. The transfer line was held at $250{ }^{\circ} \mathrm{C}$, ion source (electron impact was at $70 \mathrm{eV}$ ) at $230^{\circ} \mathrm{C}$, and quadrupole at $150^{\circ} \mathrm{C}$. Mass scan range was $29-400 \mathrm{amu}$. Identification of eluted substances was done comparing the experimental retention indices, calculated referring to linear alkanes, with those reported in literature, and by comparing the experimental mass spectra with those of the NIST 08 library.

\subsection{Squalene Analysis}

Squalene was quantified in the samples by applying a reported procedure [14]. Furthermore, $15 \mathrm{mg}$ of oil was dissolved in $1 \mathrm{~mL}$ of hexane, added $10 \mu \mathrm{L}$ of internal standard solution (squalane in hexane at $10 \mathrm{mg} \mathrm{mL}^{-1}$ ), and subjected to transmethylation with methanolic potassium hydroxide solution $(0.1 \mathrm{~mL}, 2 \mathrm{M})$. After stirring for $2 \mathrm{~min}$, the reaction was quenched by adding saturated brine $(1.5 \mathrm{~mL})$. The hexane phase was directly analysed by GC coupled to a flame ionization detector (6850, Agilent Technologies, Santa Clara, CA, USA) by injecting $1 \mu \mathrm{L}$ in the hot injector at $300{ }^{\circ} \mathrm{C}$ in a split mode (20:1 split ratio) using as chromatographic column of a $5 \%$ phenylpolydimethylsiloxane coated capillary column (HP-5, length $30 \mathrm{~m}, 0.32 \mathrm{~mm}$ i.d., $0.25 \mu \mathrm{m}$ film thickness, Agilent Technologies, Santa Clara, CA, USA) with a run time of $5 \mathrm{~min}$.

\subsection{Total Antioxidant Activity (TAA)}

The total antioxidant activity of MEVOOs and industrial EVOOs was determined according to a reported procedure [15]. This test is based on the capacity of antioxidant compounds to quench the ABTS radical cation [2,2' - azinobis (3-ethylbenzothiazoline-6-sulfonic acid) diammonium salt], 
a blue/green chromophore absorbing at $734 \mathrm{~nm}$. The decrease of absorbance is proportional to the antioxidants found in the sample. The ABTS radical cation solution was prepared by reacting $7 \mathrm{mM}$ ABTS in water with $2.5 \mathrm{mM}$ potassium sulphate. Ethanol was added to reach an absorbance of 0.7 \pm 0.2 at $734 \mathrm{~nm}$. The TAA was determined on oils 1:4 (v/v) diluted with hexane. Two mL of ABTS solution, mixed with $10 \mu \mathrm{L}$ of olive oil solution was incubated at room temperature away from light for $10 \mathrm{~min}$, and then read at $30^{\circ} \mathrm{C}$ in a spectrophotometer at $734 \mathrm{~nm}$. Solvent blanks were prepared for each assay. The absorbance decrease was referred to the calibration curve obtained in the presence of known concentrations of Trolox (6-hydroxy-2,5,7,8-tetramethylchroman-2-carboxylic acid), a vitamin E analogue, which is an antioxidant widely used as an antioxidant activity index. Results are reported in terms of Trolox concentrations $(\mu \mathrm{M})$.

\subsection{Sensory Analysis}

Sensory analysis was performed according to the procedure reported in the European Commission regulation n. 2568/1991 [16] and in its subsequent modifications. Analyses were performed by ASSAM-Marche, whose panel was authorized by the International Olive Council (IOC) until 2004, and then by the Ministry of Agricultural, Food, and Forestry Policies (MIPAAF).

\subsection{Statistical Analysis}

Statistical analysis was performed to highlight significant differences between the oil groups investigated by means of one-way analysis of variance (ANOVA) and Tukey's pairwise test using the software PAST [17]. Principal component analysis was performed by The Unscrambler X (Camo software, 2009-2012).

\section{Results and Discussion}

\subsection{Fatty Acid Composition}

One of the major key strengths of olive oil composition is its very high percent content of oleic acid and low percent content of linoleic acid bound in the acylglycerol backbone, which makes olive oil highly resistant toward oxidation, by maintaining a low level of saturated fatty acid percentage content. In Figure 1, the average percentage content of oleic acid and linoleic acid in each cultivar investigated during the two-year study are reported. Some clear features of the cvs. investigated can be highlighted. In both the years investigated, 2015 and 2016, MIG is the weakest cultivar from this point of view. In fact, it has the lowest content of oleic acid $(72.7 \pm 1.3 \%$ in 2015 and $71.4 \pm$ $1.2 \%$ in 2016) and the highest content of linoleic acid (9.2 $\pm 0.7 \%$ in 2015 and $9.4 \pm 0.8 \%$ in 2016), differing significantly $(p<0.05)$ in almost all the cases from the other cvs. Differently, MOG has the best characteristics from this point of view, having both the years with the highest average value of the oleic acid percentage, which is almost identical in the two years $(77.5 \pm 1.4 \%$ and $77.6 \pm 1.8 \%$, in 2015 and 2016, respectively), and the lowest percentage content of linoleic acid ( $6.8 \pm 0.8 \%$ and $6.5 \pm 0.7 \%$, in 2015 and 2016, respectively). These results are in total agreement with the study of Rotondi et al. [4] who reported results referring to a very high number of samples investigated. A general agreement was also found with results reported by Cecchi et al. [18] with the only exception of ASC for which they found a slightly lower percentage content of linoleic acid $(4.2 \pm 0.2 \%$ versus $6.6 \pm 0.6 \%$ of the present study) and higher oleic acid percentage $(79.8 \pm 4.0 \%$ versus $75.6 \pm 1.2 \%$ of the present study). The trend found for the different cvs. is very similar in the two years, and, considering that all the oils have been produced with olives generally harvested at the ideal ripening degree [19], the obtained results support the genetic reason for the trend found. The finding is in agreement with other studies [20,21], which allows us to recognize clear differences between the cvs. investigated. The effect of seasonality on the fatty acid composition was weak as shown by the absence of significant differences in the comparison between the two years in each of the cvs. investigated. 


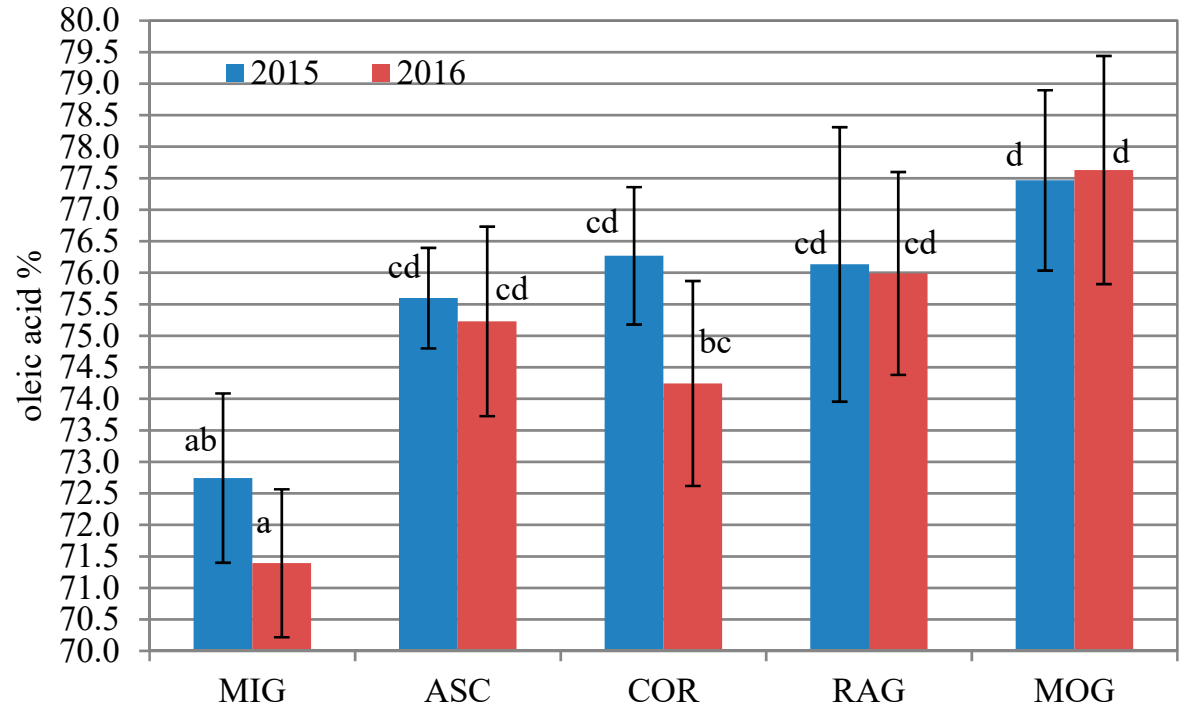

(a)

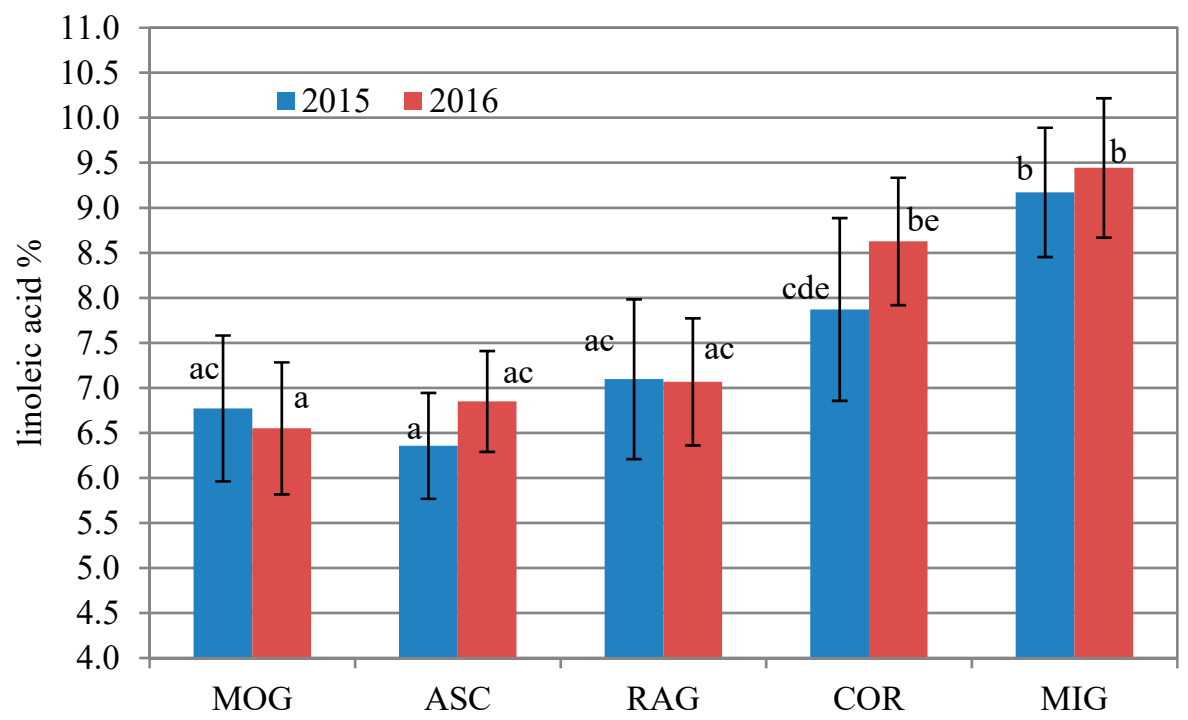

(b)

Figure 1. Oleic acid percentage (a) and linoleic acid percentage (b) in total fatty acid composition in Ascolana tenera (ASC), Coroncina (COR), Mignola (MIG), Piantone di Mogliano (MOG), and Raggia (RAG) monovarietal oils investigated, which was produced in 2015 and 2016. Bars indicate \pm standard deviation. All different letters indicate significant differences $(p<0.05$, One-way ANOVA, Tukey's test for pairwise comparison) among the 10 oil sample groups investigated.

\subsection{Polar Phenolic Substances}

Polar phenolic compounds are key components for assessing the quality of an olive oil due to their contribution to sensory, healthy, and stability properties. Within these substances, great attention has been devoted in the last years to a sub-group of phenolics indicated as "hydroxytyrosol and its derivatives like oleuropein complex and tyrosol" [22], whose concentration, when exceeding $250 \mathrm{mg} \mathrm{kg}^{-1}$ of oil, allows the acknowledgement of the health claim on olive oil polar phenolic compounds. To the best of our knowledge, the composition of polar phenolic compounds in the monovarietal oils from cvs. investigated in the present study, have never been reported earlier with the only exception of ASC, whose oils, obtained from crops cultivated in Tunisia, have been studied from this point of view [11]. Among the 79 oils investigated in the present study, 70 resulted in a 
composition that allows the acknowledgement of the mentioned health claim. Thus, this shows high quality from this point of view, similarly to what was found by Antonini et al. [23]. These authors reported that all the Italian EVOOs investigated (28 from protected designation of origin consortia and 256 from little family farms all over the Italian country) had levels allowing the acknowledgement of the health claim. The cultivar with the highest total polar phenolic compounds content (largely represented, from $89.2 \%$ to $95.0 \%$, by the substances considered by the health claim) resulted in RAG having an average total concentration of $434.2 \pm 151.2 \mathrm{mg} \mathrm{kg}^{-1}$. The one with the lowest content was MOG with an average total concentration of $318.3 \pm 123.3 \mathrm{mg} \mathrm{kg}^{-1}$ (Table 1). In addition, the average content of the total phenolic substances considered by the above-mentioned health claim does not vary significantly between the cvs. investigated. In 2015, it varies from $255.7 \pm 112.5 \mathrm{mg} \mathrm{kg}^{-1}$ found in MOG to $443.4 \pm 169.7 \mathrm{mg} \mathrm{kg}^{-1}$ found in RAG while, in 2016 , from $346.0 \pm 104.8 \mathrm{mg} \mathrm{kg}^{-1}$ in ASC to $395.7 \pm 130.5 \mathrm{mg} \mathrm{kg}^{-1}$ in COR. However, in both years, RAG is one of the two cvs. with the highest content and MOG is one of the two with the lowest content. Considering the whole of the MEVOOs investigated, their average content of the phenolic substances considered by the health claim, is higher as compared to levels reported for EVOO blends commonly found in the large retail distribution market (supermarket) [24,25]. Interesting information to fingerprint the different varieties were provided mostly by minor phenolics, like phenolic acids, lignans, and flavonoids, which seem to be more characteristic for the cvs. investigated as compared to the major phenolic substances (secoiridoid derivatives). Statistical analysis indicated that the content of acetoxypinoresinol was significantly higher in RAG ( $p=4.410^{-9}$ and $1.110^{-7}$ in 2015 and 2016 samples, respectively) than in each of the other cvs. investigated in both years. The finding is in agreement with other studies pointing at lignans as possible varietal markers [26]. Regarding phenolic acids, MOG and MIG had the highest content of $p$-coumaric acid and vanillic acid, respectively, in both years.

\section{3. $\alpha$-Tocopherol}

The average content of $\alpha$-tocopherol in the different cvs. investigated resulted in an identical trend in the two years. The cultivar having the highest content was MIG, with an average content of $295.9 \pm 25.7 \mathrm{mg} \mathrm{kg}^{-1}$ in 2015 and of $397.3 \pm 39.9 \mathrm{mg} \mathrm{kg}^{-1}$ in 2016, which was followed by ASC and then by COR, RAG, and MOG, which contained the lowest average amount: $192.3 \pm 42.2 \mathrm{mg} \mathrm{kg}^{-1}$ in 2015 and $259.0 \pm 44.2 \mathrm{mg} \mathrm{kg}^{-1}$ in 2016 (Table 1). Thus, the results indicate a clear relation of the tocopherol content with the cultivar, which was also shown in other studies [27-29]. The average content was higher in 2016 as compared to 2015 for each of the cvs. investigated with statistical significance at $p<0.05$ for COR and MIG. Thus, this reveals an effect of the pedo-climatic, agronomic conditions, rather independent from the cultivar. 
Table 1. Average content of polar phenolic substances and of $\alpha$-tocopherol \pm standard deviation (SD) in the investigated monovarietal oils (ASC: Ascolana tenera, COR: Coroncina, MIG: Mignola, MOG: Piantone di Mogliano, RAG: Raggia) produced in 2015 and 2016 and in the total 2015/2016 samples.

\begin{tabular}{|c|c|c|c|c|c|c|c|c|c|c|c|c|}
\hline & Hydroxytyrosol & Tyrosol & $\begin{array}{l}\text { Vanillic } \\
\text { Acid }\end{array}$ & $\begin{array}{c}p \text {-Coumaric } \\
\text { Acid }\end{array}$ & Ferulic Acid & $\begin{array}{l}\text { Secoiridoid } \\
\text { Derivatives }\end{array}$ & Pinoresinol & $\begin{array}{c}\text { Acetoxy } \\
\text { pinoresinol }\end{array}$ & Luteolin & Apigenin & $\begin{array}{l}\text { Total Polar } \\
\text { Phenolics }\end{array}$ & $\alpha$-Tocopherol \\
\hline & \multicolumn{12}{|c|}{ Average $\left(\mathrm{mg} \mathrm{kg}^{-1}\right) \pm \mathrm{SD}$} \\
\hline $\begin{array}{c}\mathrm{ASC} 2015 \\
(n=6)\end{array}$ & $5.46^{\mathrm{ab}} \pm 2.14$ & $6.00 \pm 2.97$ & $0.33 \pm 0.16$ & $0.10^{\mathrm{ab}} \pm 0.03$ & $0.03^{\mathrm{a}} \pm 0.02$ & $353.23 \pm 108.89$ & $12.49^{\mathrm{a}} \pm 5.55$ & $5.98^{\mathrm{a}} \pm 7.54$ & $2.30 \mathrm{ab} \pm 0.59$ & $0.90^{\mathrm{b}} \pm 0.34$ & $387.80^{\mathrm{ab}} \pm 182.13$ & 270.91 adc \pm 39.50 \\
\hline $\begin{array}{l}\text { COR } 2015 \\
(n=7)\end{array}$ & $4.06^{\mathrm{a}} \pm 1.62$ & $4.67 \pm 1.39$ & $0.32 \pm 0.17$ & $0.11^{\mathrm{a}} \pm 0.04$ & $0.03^{\mathrm{a}} \pm 0.03$ & $340.19 \pm 109.02$ & $4.72^{b} \pm 1.56$ & $8.86^{\mathrm{a}} \pm 8.34$ & $3.24^{\mathrm{b}} \pm 1.16$ & $1.25^{\mathrm{b}} \pm 0.31$ & $367.45^{\mathrm{ab}} \pm 113.52$ & \# 229.92 bc \pm 16.48 \\
\hline $\begin{array}{l}\text { MIG } 2015 \\
(n=7)\end{array}$ & $8.75^{b} \pm 5.16$ & $9.24 \pm 6.16$ & $0.49 \pm 0.23$ & $0.09 \mathrm{ab} \pm 0.03$ & $0.03^{a} \pm 0.02$ & $282.14 \pm 113.72$ & $\# 6.48^{\mathrm{b}} \pm 1.58$ & $8.13^{\mathrm{a}} \pm 1.69$ & $2.10^{\mathrm{ab}} \pm 0.47$ & $0.49^{\mathrm{a}} \pm 0.15$ & $317.94 \mathrm{ab} \pm 121.26$ & \# $295.94^{\mathrm{a}} \pm 25.69$ \\
\hline $\begin{array}{c}\text { MOG } 2015 \\
(n=9)\end{array}$ & $2.38^{a} \pm 1.53$ & $5.11 \pm 1.22$ & $0.46 \pm 0.21$ & $0.12^{\mathrm{a}} \pm 0.04$ & $0.08^{\mathrm{b}} \pm 0.02$ & $248.22 \pm 112.33$ & $7.63 \mathrm{ab} \pm 2.33$ & $5.31^{\mathrm{a}} \pm 4.32$ & $1.49^{\mathrm{a}} \pm 0.95$ & $0.94^{\mathrm{b}} \pm 0.30$ & $271.73^{\mathrm{a}} \pm 112.89$ & $192.35^{\mathrm{b}} \pm 42.15$ \\
\hline $\begin{array}{c}\text { RAG 2015 } \\
(n=7)\end{array}$ & $\# 6.79 \mathrm{ab} \pm 2.79$ & $6.86 \pm 2.59$ & $0.34 \pm 0.14$ & $\# 0.05^{b} \pm 0.02$ & $0.05^{\mathrm{ab}} \pm 0.02$ & $429.75 \pm 172.33$ & $\# 3.83^{b} \pm 0.54$ & $35.47^{b} \pm 10.34$ & $3.08^{\mathrm{b}} \pm 1.47$ & $1.25^{\mathrm{b}} \pm 0.18$ & $487.48^{\mathrm{b}} \pm 175.89$ & $215.98^{\mathrm{bc}} \pm 47.51$ \\
\hline $\begin{array}{c}\text { ASC } 2016 \\
(n=8)\end{array}$ & $5.01 \pm 2.86$ & $6.24 \pm 3.76$ & $0.31 \pm 0.19$ & $0.12 \pm 0.04$ & $0.06 \pm 0.02$ & $334.77 \pm 104.17$ & $18.45^{\mathrm{a}} \pm 14.09$ & $8.94^{\mathrm{a}} \pm 9.22$ & $3.04^{\mathrm{ab}} \pm 0.99$ & $0.92^{\mathrm{ab}} \pm 0.24$ & $377.90 \pm 103.23$ & $356.68^{\mathrm{bc}} \pm 81.67$ \\
\hline $\begin{array}{c}\text { COR 2016 } \\
(n=7)\end{array}$ & $5.32 \pm 2.16$ & $5.78 \pm 2.78$ & $0.35 \pm 0.25$ & $0.14 \pm 0.06$ & $0.05 \pm 0.03$ & $384.59 \pm 127.68$ & $6.27^{b} \pm 1.25$ & $5.52^{\mathrm{a}} \pm 4.65$ & $3.61^{\mathrm{ab}} \pm 0.76$ & $1.20^{\mathrm{b}} \pm 0.19$ & $412.86 \pm 133.15$ & $\S 351.16^{\mathrm{bc}} \pm 50.76$ \\
\hline $\begin{array}{l}\text { MIG } 2016 \\
(n=8)\end{array}$ & $6.37 \pm 1.98$ & $5.53 \pm 2.41$ & $0.52 \pm 0.47$ & $0.09 \pm 0.05$ & $0.05 \pm 0.02$ & $339.73 \pm 105.57$ & $\S 9.70 \mathrm{ab} \pm 1.74$ & $10.30^{\mathrm{a}} \pm 5.03$ & $2.51^{\mathrm{ab}} \pm 0.63$ & $0.59^{\mathrm{a}} \pm 0.28$ & $375.47 \pm 105.31$ & $\S 397.26^{\mathrm{b}} \pm 36.94$ \\
\hline $\begin{array}{c}\text { MOG 2016 } \\
(n=8)\end{array}$ & $4.94 \pm 5.46$ & $7.47 \pm 6.65$ & $0.35 \pm 0.16$ & $0.18 \pm 0.12$ & $0.07 \pm 0.04$ & $335.27 \pm 112.60$ & $10.29^{\mathrm{ab}} \pm 5.77$ & $9.03^{\mathrm{a}} \pm 6.41$ & $2.06^{\mathrm{a}} \pm 0.75$ & $0.92^{\mathrm{ab}} \pm 0.29$ & $370.68 \pm 119.33$ & $259.01^{\mathrm{a}} \pm 44.19$ \\
\hline $\begin{array}{c}\text { RAG } 2016 \\
(n=12)\end{array}$ & $\S 3.83 \pm 2.08$ & $6.20 \pm 3.66$ & $0.44 \pm 0.26$ & $\S_{0.13} \pm 0.09$ & $0.07 \pm 0.04$ & $349.47 \pm 131.68$ & $\S 5.98^{\mathrm{b}} \pm 2.31$ & $31.77^{b} \pm 12.38$ & $4.05^{b} \pm 2.14$ & $1.10^{\mathrm{b}} \pm 0.41$ & $403.13 \pm 132.91$ & $286.66^{\mathrm{ac}} \pm 67.26$ \\
\hline $\begin{array}{c}\text { ASC 2015/2016 } \\
(n=14)\end{array}$ & $5.21^{\mathrm{ab}} \pm 2.50$ & $5.40 \pm 2.00$ & $0.32 \pm 0.17$ & $0.11 \pm 0.04$ & $0.05^{\mathrm{a}} \pm 0.02$ & $342.68 \pm 102.44$ & $15.90^{\mathrm{a}} \pm 11.32$ & $7.67^{\mathrm{a}} \pm 8.36$ & $2.72^{\mathrm{ab}} \pm 0.90$ & $0.91^{\mathrm{b}} \pm 0.27$ & $376.97 \pm 103.64$ & $322.37^{\mathrm{bc}} \pm 79.12$ \\
\hline $\begin{array}{c}\text { COR 2015/2016 } \\
(n=14)\end{array}$ & $4.69^{\mathrm{ab}} \pm 1.95$ & $5.13 \pm 1.98$ & $0.34 \pm 0.21$ & $0.12 \pm 0.05$ & $0.04^{\mathrm{a}} \pm 0.03$ & $362.39 \pm 116.37$ & $5.49^{\mathrm{b}} \pm 1.58$ & $7.19^{\mathrm{a}} \pm 6.71$ & $3.42^{b c} \pm 0.96$ & $1.23^{c} \pm 0.25$ & $390.16 \pm 121.19$ & $294.58^{\mathrm{bc}} \pm 72.97$ \\
\hline $\begin{array}{l}\text { MIG 2015/2016 } \\
\quad(n=15)\end{array}$ & $7.48^{\mathrm{a}} \pm 3.86$ & $6.53 \pm 3.17$ & $0.51 \pm 0.36$ & $0.09 \pm 0.04$ & $0.04^{\mathrm{a}} \pm 0.02$ & $312.85 \pm 109.54$ & $8.20^{b} \pm 2.31$ & $9.29^{\mathrm{a}} \pm 3.89$ & $2.32^{\mathrm{ab}} \pm 0.58$ & $0.54^{\mathrm{a}} \pm 0.22$ & $348.63 \pm 112.83$ & $349.98^{\mathrm{b}} \pm 60.85$ \\
\hline $\begin{array}{l}\text { MOG 2015/2016 } \\
\quad(n=17)\end{array}$ & $3.58^{\mathrm{b}} \pm 3.99$ & $6.13 \pm 3.36$ & $0.40 \pm 0.19$ & $0.15 \pm 0.09$ & $0.07^{b} \pm 0.03$ & $289.19 \pm 117.74$ & $8.88^{\mathrm{b}} \pm 4.37$ & $7.06^{\mathrm{a}} \pm 5.57$ & $1.76^{\mathrm{a}} \pm 0.88$ & $0.93^{b} \pm 0.29$ & $318.30 \pm 123.26$ & $219.01^{\mathrm{a}} \pm 53.43$ \\
\hline $\begin{array}{c}\text { RAG 2015/2016 } \\
(n=19)\end{array}$ & $4.92^{\mathrm{ab}} \pm 2.72$ & $8.29 \pm 6.26$ & $0.40 \pm 0.22$ & $0.10 \pm 0.08$ & $0.06^{\mathrm{ab}} \pm 0.03$ & $379.05 \pm 148.59$ & $5.19^{\mathrm{b}} \pm 2.12$ & $33.14^{\mathrm{b}} \pm 11.52$ & $3.70^{\mathrm{c}} \pm 1.94$ & $1.16^{\mathrm{bc}} \pm 0.34$ & $434.21 \pm 151.18$ & $260.62^{\mathrm{ac}} \pm 68.88$ \\
\hline
\end{tabular}

Statistical analysis compares the five different cultivars in the same year (2015 and 2016) and in the two years 2015/2016 (significant differences at $p<0.05$ are highlighted by different letters). The same cultivar is also compared in the two different years and significant differences at $p<0.05$ are highlighted by different symbols. 


\subsection{Volatile Substances}

In this study, a selection of volatile molecules among those detected in the EVOOs investigated, has been considered, based on their recognized relation with positive or negative sensory attributes of an olive oil. Their relative quantification has been performed in terms of peak area percentage, and significant differences between the cvs. were highlighted in each of the two years investigated (Table 2), with some features seeming to be peculiar of the cultivar, as suggested by an identical trend in both years. Volatile substances are key compounds concerning the sensory properties of an EVOO where they can provide positive sensory notes as the green, fruity, almond and many other desirable attributes. However, some of the volatiles (e.g., ethanol, acetic acid, some aldehydes) are also responsible for negative sensory attributes of the oil (e.g., rancid, winey, yeast). Thus, the profile of the volatile substances can be related to the quality of an EVOO highlighting some peculiarities of the specific olive cultivar from which the oil has been obtained. The lipoxygenase pathway is the key biochemical process leading to formation of a series of volatile molecules, mainly having five or six carbons, that are aldehydes, alcohols, or their ester derivatives with acetic acid. (E)-2-Hexenal, which is one of the main compounds formed in the lipoxygenase pathway, is a key molecule in EVOO flavor, which contributes with sensory notes of green leaves, grass, and fruit and is commonly found to be the most abundant volatile detected. Other aldehydes are present in EVOO and their presence, referring in particular to longer chain aldehydes, as e.g., 2-heptenal, nonanal, and decanal [30], which is due to autoxidation phenomena leading the oil to lose its sensory and nutritional quality, beyond its safety. Pentene dimers are a group of isomers formed during lipoxygenase pathway, which have been associated with positive sensory attributes of the oil [31]. Terpenes (e.g., $\alpha$-farnesene, $\alpha$-copaene) are also commonly found in EVOO and their presence has been related to the olive cultivar, which has molecules already present in the olive fruit and are partially transferred to the oil during the production. $\alpha$-Copaene is a tricyclic sesquiterpene whose presence in the fruit has been reported to contribute to an increase in the susceptibility of olive fruits to attack by Bactrocera oleae females [32]. Methanol and ethanol are produced to a large extent in undesirable fermentation processes occurring during prolonged olives storage before processing and higher levels are generally found in oils having lower quality [33-35]. In the present study, oils from the cultivar ASC were characterised by a high average percent of the C5 compounds 1-penten-3-one and 1-penten-3-ol, by (Z)-3-hexen-1-ol and 3-hexen-1-ol acetate and by a low relative percentage of (E)-2-hexenal (Table 2). MIG had a high percent of 3-hexen-1-ol and hexanol acetates, pentene dimers, and $\alpha$-farnesene, which was highest in MIG in each of the two years even if statistical significance was not reached in 2016. On the other side, MIG was relatively poor of 1-penten-3-one and 1-penten-3-ol, (E)-2-hexenal, hexanal, and $\alpha$-copaene. In both years investigated, RAG was the cultivar with the highest average percentage of $(E)$-2-hexenal, $82.2 \pm 4.6 \%$ in 2015 and $72.1 \pm 10.3 \%$ in 2016, which is significantly higher than its average percentage of content in MIG and in ASC in both years. The absolute content of the molecule, measured in terms of peak area units, has the same trend, with RAG having the highest average value, as compared to the other cvs. in both years, and differing significantly from MIG in both years. MOG variety was characterised by the highest percent content of $\alpha$-copaene in each of the two years, with significant differences among the groups investigated, which points at $\alpha$-copaene as a possible marker for the variety. The result is in agreement with the study of Cecchi and Alfei [9], where $\alpha$-copaene percentage in the volatile composition of 11 different monovarietal oils investigated resulted in the highest value in MOG. The high content of this volatile could also possibly cause this cultivar to be more susceptible to the attack by B. oleae [32]. 
Table 2. Average percent composition in terms of peak area percentage \pm standard deviation (SD) of selected volatile compounds analysed by head-space solid-phase microextraction and gas chromatography coupled to mass spectrometry, in the investigated monovarietal oils (ASC: Ascolana tenera, COR: Coroncina, MIG: Mignola, MOG: Piantone di Mogliano, RAG: Raggia) produced in 2015 and 2016 and in the total 2015/2016 samples.

\begin{tabular}{|c|c|c|c|c|c|c|c|c|c|c|c|c|c|c|c|c|c|c|c|c|c|}
\hline & Methanol & Ethanol & 3-Pentanone & 1-Penten-3-one & $\begin{array}{l}\text { 4,8-Dimethyl- } \\
\text { 1,7-Nonadiene }\end{array}$ & 1-Penten-3-ol & (E)-2-Hexenal & $\begin{array}{l}\text { Hexyl } \\
\text { Acetate }\end{array}$ & Hexanal & Octanal & $\begin{array}{l}\text { (Z)-3-Hexen-1-ol } \\
\text { Acetate }\end{array}$ & (Z)-2-Penten-1-ol & $\begin{array}{l}\text { 6-Methyl-5- } \\
\text { Hepten-2-one }\end{array}$ & 1-Hexanol & (Z)-3-Hexen-1-ol & (E)-2-Hexen-1-ol & Nonanal & $\alpha$-Copaene & 1-Octanol & $\alpha$-Farnesene & $\begin{array}{l}\text { Total } \\
\text { Pentene } \\
\text { Dimers }\end{array}$ \\
\hline & \multicolumn{21}{|c|}{ Area $\% \pm S D$} \\
\hline $\begin{array}{c}\text { ASC 2015 } \\
(n=6)\end{array}$ & $\begin{array}{l}\begin{array}{l}3.5 .54 \mathrm{ab} \\
\pm 2.96\end{array} \\
\pm\end{array}$ & $\begin{array}{l}{ }_{66.11 \pm} \\
6.46\end{array}$ & ${ }^{11.68} \mathrm{ab}^{\mathrm{ab}} \pm$ & $3.83 \pm 1.96$ & $1.07 \pm 0.70$ & $1.91^{\mathrm{b}} \pm 1.61$ & $49.84^{a} \pm 17.41$ & $\begin{array}{c}0.67^{\mathrm{acc}} \\
0.15\end{array}$ & $\begin{array}{l}4.45 \text { abc } \\
\pm 3.78 \\
\end{array}$ & $\begin{array}{c}0.68 \pm \\
0.76\end{array}$ & $6.23 \pm 1.63$ & ${ }^{*} 0.18 \pm 0.18$ & nd & $\begin{array}{l}2.533^{\mathrm{ab}} \pm \\
1.83\end{array}$ & $" 11.15^{b} \pm 9.84$ & $0.81 \pm 0.53$ & $\begin{array}{l}2.92 \pm \\
2.66\end{array}$ & $0.68 \mathrm{ab} \pm 0.75$ & $0.31 \pm 0.51$ & $0.21^{a} \pm 0.37$ & $\begin{array}{l}4.94^{\mathrm{abb}} \pm \\
4.49^{-}\end{array}$ \\
\hline $\begin{array}{c}\text { COR } 201 \\
(n=7)\end{array}$ & $\begin{array}{l}3.2 .2{ }^{3} \pm \\
1.59 \\
\end{array}$ & $\begin{array}{l}3.07 \pm \\
2.72 \\
\end{array}$ & $0.75^{\mathrm{a}} \pm 0.58$ & $3.16 \pm 1.87$ & $1.10 \pm 0.64$ & $0.90 \mathrm{ab} \pm 0.42$ & $64.96 \mathrm{ab} \pm 11.84$ & $\begin{array}{c}0.51 \mathrm{bcc} \\
0.49\end{array}$ & $\begin{array}{c}2.38^{\mathrm{c}} \pm \\
1.50\end{array}$ & $\begin{array}{c}0.28 \pm \\
0.35 \\
\end{array}$ & $" 1.89 \pm 1.25$ & ${ }^{* 0.32 \pm 0.53}$ & nd & $\begin{array}{l}1.63^{a} \pm \\
1.94\end{array}$ & $3.04^{\mathrm{a}} \pm 2.08$ & $1.83 \pm 1.37$ & $\begin{array}{l}2.25 \pm \\
3.18 \\
\end{array}$ & $0.25^{b} \pm 0.24$ & $0.08 \pm 0.14$ & $0.35^{a} \pm 0.20$ & $\begin{array}{l}8.02^{a} \pm \\
3.46\end{array}$ \\
\hline $\begin{array}{c}\text { MIG } 2015 \\
(n=7)\end{array}$ & $\begin{array}{l}\begin{array}{c}41.82 \text { ab } \\
\pm 1.06\end{array} \\
\end{array}$ & $\begin{array}{l}6.74 \pm \\
5.02\end{array}$ & 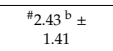 & $1.41 \pm 1.11$ & $1.23 \pm 0.33$ & $0.83^{\mathrm{ab}} \pm 0.34$ & $47.60^{a} \pm 22.76$ & $\begin{array}{c}1.12^{a} \pm \\
0.44\end{array}$ & $\begin{array}{l}1.97^{\mathrm{c}} \pm \\
1.20\end{array}$ & $\begin{array}{c}0.32 \pm \\
0.11\end{array}$ & $4.71 \pm 2.47$ & ${ }^{*} 0.10 \pm 0.09$ & $0.13 \pm 0.15$ & $\begin{array}{l}5.36^{\mathrm{b}} \pm \\
4.27\end{array}$ & ${ }_{4.72} \mathrm{ab}^{\mathrm{ab}} \pm 2.96$ & $9.11 \pm 1.74$ & $\begin{array}{l}1.28 \pm \\
0.53\end{array}$ & $0.04^{\mathrm{b}} \pm 0.10$ & nd & $0.98^{\mathrm{b}} \pm 0.58$ & $\begin{array}{l}8.09^{9} \pm \\
2.22\end{array}$ \\
\hline $\begin{array}{l}\mathrm{MOG} \\
2015 \\
(n=9)\end{array}$ & $\begin{array}{c}1.75 \text { ab }^{1.16} \\
1.16\end{array}$ & $\begin{array}{l}3.04 \pm \\
3.69\end{array}$ & $\frac{{ }_{1} 1.20 \mathrm{ab}}{0.82} \pm$ & $2.42 \pm 1.17$ & ${ }^{0} 0.60 \pm 0.33$ & $1.19 \mathrm{ab} \pm 0.68$ & $64.68 \mathrm{ab} \pm 11.02$ & $\begin{array}{l}0.03^{\mathrm{b}} \pm \\
0.09\end{array}$ & $\frac{6.5 \mathrm{~b}^{\mathrm{b}} \pm}{3.00^{-1}}$ & $\begin{array}{l}0.20 \pm \\
0.19\end{array}$ & $0.27 \pm 0.49$ & ${ }^{*} 0.14 \pm 0.13$ & nd & $\begin{array}{l}2.12^{\mathrm{ab}} \pm \\
1.15\end{array}$ & $77.25^{a} \pm 3.75$ & $\|_{2.28} \pm 1.72$ & $\begin{array}{l}0.97 \pm \\
0.84\end{array}$ & $0^{\mathrm{a}} \pm 0.56$ & nd & $8^{\mathrm{a}} \pm 0.12$ & $\begin{array}{l}3.8 .8 \text { ab } \\
1.66\end{array}$ \\
\hline $\begin{array}{c}\text { RAG } 2015 \\
(n=7)\end{array}$ & $\begin{array}{l}0.60^{b} \pm \\
0.38\end{array}$ & $\begin{array}{l}1.87 \pm \\
1.45 \\
\end{array}$ & $0.52^{a} \pm 0.52$ & $1.63 \pm 1.03$ & $*_{0.50 \pm 0.18}$ & $0.57^{\mathrm{a}} \pm 0.30$ & ${ }^{\#} 82.91^{\mathrm{b}} \pm 4.60$ & $\begin{array}{c}0.09 \mathrm{~b} \pm \\
0.13\end{array}$ & $\begin{array}{c}1.84 \mathrm{c}^{\mathrm{c}} \\
0.50 \\
\end{array}$ & $\begin{array}{c}0.20 \pm \\
0.10 \\
\end{array}$ & $0.43 \pm 0.34$ & ${ }^{*} 0.10 \pm 0.06$ & nd & $\begin{array}{l}1.41^{\mathrm{a}} \pm \\
0.97 \\
\end{array}$ & ${ }^{*} 0.84^{\mathrm{a}} \pm 0.18$ & $2.27 \pm 9.97$ & $\begin{array}{l}1.43 \pm \\
1.28 \\
\end{array}$ & $0.16^{b} \pm 0.14$ & $0.06 \pm 0.08$ & $0.08^{a} \pm 0.14$ & $\begin{array}{c}{ }_{22.47^{\mathrm{b}}} \\
1.63\end{array}$ \\
\hline 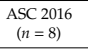 & $\begin{array}{l}s_{1.01 \pm} \pm \\
1.46 \\
\end{array}$ & $\begin{array}{c}8_{0.43 \pm} \\
0.21 \\
\end{array}$ & $8_{0.44 \pm 0.64}$ & $3.16 \pm 3.58$ & $1.29 \pm 1.66$ & $0.94 \pm 0.79$ & $53.26^{\mathrm{a}} \pm 13.23$ & $\begin{array}{c}1.08 \text { abc } \\
0.83\end{array}$ & $\begin{array}{l}4.03 \pm \\
1.21\end{array}$ & $\begin{array}{c}0.69 \pm \\
0.83 \\
\end{array}$ & $4.94 \pm 3.43$ & $\S_{0.78 \pm 0.45}$ & $0.10 \pm 0.15$ & $1.66 \pm 0.86$ & $\S_{4.61^{c}+1.04}$ & $3.92 \pm 3.88$ & $\begin{array}{l}8.51 \pm \\
8.43\end{array}$ & $0.14^{a} \pm 0.33$ & $0.69 \pm 0.99$ & $0.15 \pm 0.17$ & $8.14 \pm 3.90$ \\
\hline $\begin{array}{c}\text { COR 2016 } \\
(n=7)\end{array}$ & $\begin{array}{c}\$ 1.43 \pm \\
0.64\end{array}$ & $\begin{array}{l}2.36 \pm \\
2.76\end{array}$ & $0.57 \pm 0.54$ & $2.51 \pm 1.31$ & $1.42 \pm 1.45$ & $0.77 \pm 0.39$ & $58.58 \mathrm{ab} \pm 2.79$ & $\begin{array}{l}1.188^{\mathrm{acc} \pm} \\
0.86 \mathrm{~F}\end{array}$ & $\begin{array}{c}3.21 \pm \\
1.86 \\
\end{array}$ & $\begin{array}{c}0.12 \pm \\
0.28\end{array}$ & $8_{6.22} \pm 3.51$ & $\$_{1.23} \pm 0.50$ & nd & $1.58 \pm 0.81$ & $3.322^{b c} \pm 1.13$ & $2.55 \pm 1.62$ & $\begin{array}{l}2.72 \pm \\
2.98\end{array}$ & $0.02^{\mathrm{a}} \pm 0.05$ & $0.09 \pm 0.21$ & $0.17 \pm 0.19$ & $9.52 \pm 3.70$ \\
\hline $\begin{array}{l}\text { MIG 2016 } \\
(n=8)\end{array}$ & $\begin{array}{c}8_{0.62 \pm} \\
0.44 \\
\end{array}$ & $\begin{array}{l}2.22 \pm \\
2.50 \\
\end{array}$ & $8_{0.38 \pm 0.42}$ & $1.03 \pm 0.80$ & $1.25+1.00$ & $0.39 \pm 0.37$ & $52.36^{a} \pm 15.19$ & $\begin{array}{c}1.54^{\mathrm{a}} \mathrm{\pm} \\
0.75 \\
\end{array}$ & $\begin{array}{l}3.63 \pm \\
2.15 \\
\end{array}$ & $\begin{array}{c}0.54 \pm \\
1.00 \\
\end{array}$ & $6.48 \pm 4.05$ & $8_{0.73 \pm 0.45}$ & $0.13 \pm 0.17$ & $1.68 \pm 0.93$ & $.63^{a c} \pm 0.84$ & $2.31 \pm 1.67$ & $\begin{array}{l}8.32 \pm \\
9.52 \\
\end{array}$ & nd & $0.28 \pm 0.42$ & $0.95 \pm 0.73$ & $\begin{array}{l}12.75 \pm \\
7.60\end{array}$ \\
\hline $\begin{array}{l}\mathrm{MOG} \\
2016 \\
(n=8) \\
(n)\end{array}$ & $\begin{array}{l}1.07 \pm \\
0.61\end{array}$ & $\begin{array}{l}1.48 \pm \\
1.85\end{array}$ & ${ }^{s_{0.29}} \pm 0.37$ & $1.67 \pm 1.28$ & $\$_{1.11 \pm 1.28}$ & $0.48 \pm 0.39$ & 7.14 & $\frac{0.0^{\mathrm{d}} \pm}{0.09}$ & $\begin{array}{l}3.84 \pm \\
2.47\end{array}$ & nd & $3 \pm 0.74$ & $64 \pm 0.48$ & $0.24 \pm 0.40$ & $2.08 \pm 1.95$ & $\mathrm{~d} \pm 1.62$ & $\$_{4.51 \pm 4.60}$ & $\begin{array}{l}2.57 \pm \\
3.30\end{array}$ & $5^{\mathrm{b}} \pm 0.32$ & nd & $85 \pm 1.28$ & $8.24 \pm 5.88$ \\
\hline $\begin{array}{c}\text { RAG 2016 } \\
(n=12)\end{array}$ & $\begin{array}{c}0.66 \pm \\
0.52 \\
\end{array}$ & $\begin{array}{l}1.00 \pm \\
0.84 \\
\end{array}$ & $0.42 \pm 0.54$ & $1.43 \pm 0.71$ & $\$_{2.17} \pm 1.11$ & $0.48 \pm 0.14$ & ${ }_{772.11^{b}} \pm 10.35$ & $\begin{array}{c}0.34^{\text {bed }} \\
0.25 \\
\end{array}$ & $\begin{array}{l}2.61 \pm \\
1.23 \\
\end{array}$ & $\begin{array}{r}0.30 \pm \\
0.68 \\
\end{array}$ & $0.69 \pm 0.77$ & $\$_{0.70 \pm 0.35}$ & $0.03 \pm 0.07$ & $1.59 \pm 1.52$ & $\$_{1.1 .15^{a} \pm 0.55}$ & $3.54 \pm 2.82$ & $\begin{array}{l}3.92 \pm \\
8.92 \\
\end{array}$ & $0.01^{a} \pm 0.05$ & $0.21 \pm 0.49$ & $0.18 \pm 0.20$ & $\begin{array}{c}\$_{6.46 \pm} \\
2.05 \\
\end{array}$ \\
\hline $\begin{array}{c}\text { ASC } \\
2101515016 \\
(n=14) \\
\end{array}$ & $\begin{array}{l}2.10 \text { ab } \pm \\
2.49\end{array}$ & $\begin{array}{l}2.32 \pm \\
4.38\end{array}$ & $0.91 \pm 1.07$ & $3.38^{\mathrm{b}} \pm 3.05$ & $1.21 \pm 1.33$ & $1.32^{\mathrm{b}} \pm 1.21$ & $51.88^{\mathrm{b}} \pm 14.01$ & $\begin{array}{l}0.955^{\mathrm{bc}} \pm \\
0.69\end{array}$ & $\begin{array}{l}4 . \mathrm{abc}_{ \pm} \\
2.21\end{array}$ & $\frac{0.69^{\mathrm{b}} \pm}{0.77}$ & $5.37^{\mathrm{a}} \pm 2.93$ & $0.55 \pm 0.47$ & $0.06 \pm 0.13$ & $1.99 \pm 1.32$ & $6.79^{\mathrm{c}} \pm 6.12$ & $2.72 \pm 3.37$ & $\begin{array}{l}6.36 \pm \\
7.20\end{array}$ & $0.35^{a} \pm 0.57$ & $0.55 \pm 0.84$ & $0.17^{\mathrm{ab}} \pm 0.25$ & $\underset{6.91 \mathrm{ab} \pm}{4.27}$ \\
\hline $\begin{array}{l}\begin{array}{c}\text { COR } \\
2015 / 2016 \\
(n=14)\end{array} \\
\end{array}$ & $\begin{array}{l}2.33^{a} \pm \\
1.49\end{array}$ & $\begin{array}{l}2.74 \pm \\
2.64\end{array}$ & $0.67 \pm 0.55$ & 2.8 & $1.25 \pm 1.05$ & $0.84^{\mathrm{ab}} \pm 0.40$ & $62.08^{\mathrm{bc}} \pm 9.17$ & $\begin{array}{l}0.82^{\text {cd }} \pm \\
0.74\end{array}$ & $\begin{array}{c}2.77^{\mathrm{c}} \pm \\
1.66\end{array}$ & 0.20 ab \pm & $3.89 \mathrm{abc} \pm 3.31$ & $0.74 \pm 0.69$ & nd & $1.61 \pm 1.47$ & \pm 1.64 & $2.16 \pm 1.47$ & $\begin{array}{l}2.67 \pm \\
3.00\end{array}$ & $0.15^{\mathrm{a}} \pm 0.21$ & $0.08 \pm 0.17$ & $0.27^{\mathrm{ab}} \pm 0.21$ & $\begin{array}{c}8.7 \mathrm{ab}_{\mathrm{ab}} \\
3.50\end{array}$ \\
\hline $\begin{array}{c}\text { MIG } \\
2015 / 5016 \\
(n=15)\end{array}$ & $\begin{array}{l}1.188^{\mathrm{ab}} \pm \\
0.98\end{array}$ & $\begin{array}{c}3.96 \pm \\
4.16\end{array}$ & $1.17 \pm 1.36$ & \pm 0.91 & $1.24 \pm 0.79$ & $0.56^{\mathrm{a}} \pm 0.41$ & $50.43^{b} \pm 17.68$ & $\begin{array}{l}1.33^{\mathrm{b}} \pm \\
0.66\end{array}$ & $\begin{array}{l}2.99 \mathrm{c} \pm \\
1.97\end{array}$ & $0.40^{\text {ab }} \pm$. & $=3.52$ & $0.48 \pm 0.47$ & $0.13 \pm 0.15$ & $3.21 \pm 3.27$ & \pm 2.11 & $4.93 \pm 6.83$ & $\begin{array}{l}5.62 \pm \\
8.10\end{array}$ & \pm 0.06 & $0.17 \pm 0.35$ & 0.65 & $\begin{array}{c}10.95^{b} \pm \\
6.39\end{array}$ \\
\hline $\begin{array}{c}\text { MOG } \\
2015 / 2016 \\
(n=17)\end{array}$ & $\begin{array}{c}1.433^{\text {ab }} \pm \\
0.98\end{array}$ & $\begin{array}{l}2.3 .36 \\
3.05 \\
\end{array}$ & $0.78 \pm 0.78$ & $2.07 \mathrm{ab} \pm 1.24$ & $0.84 \pm 0.91$ & $0.86^{\mathrm{ab}} \pm 0.66$ & 65.69 ac \pm 9.15 & $\begin{array}{c}0.03^{\mathrm{a}} \pm \\
0.09 \\
\end{array}$ & $\begin{array}{c}5.311^{\mathrm{b}} \pm \\
3.33^{-}\end{array}$ & $\underbrace{0.10^{a} \pm}_{0.17}$ & $0.30^{\mathrm{d}} \pm 0.60$ & $0.37 \pm 0.42$ & $0.11 \pm 0.29$ & $2.10 \pm 1.51$ & $5.29^{\mathrm{bc}} \pm 3.58$ & $3.32 \pm 3.44$ & $\begin{array}{l}1.72 \pm \\
2.39\end{array}$ & $0.84^{b} \pm 0.48$ & nd & $0.44^{a} \pm 0.93$ & $\begin{array}{c}5.87^{ \pm} \pm \\
4.63 \\
\end{array}$ \\
\hline $\begin{array}{c}\begin{array}{c}\text { RAG } \\
2115 / 2016 \\
(n=19)\end{array} \\
\end{array}$ & $\frac{0.64^{\mathrm{b}} \pm}{0.46^{-1}}$ & $\begin{array}{l}1.32 \pm \\
1.15\end{array}$ & $0.46 \pm 0.52$ & \pm 0.82 & 1.20 & $0.51^{\mathrm{a}} \pm 0.21$ & $76.09^{\mathrm{a}} \pm 9.98$ & $\frac{0.25 \text { ac }}{0.24}$ & $\begin{array}{c}2.33 \mathrm{c}^{\mathrm{c}} \pm \\
1.07\end{array}$ & $0.26^{\mathrm{ab} \pm} \pm$ & $0.60^{\text {bed }} \pm 0.65$ & 0.40 & 06 & $1.52 \pm 1.32$ & 1.03 & $3.07 \pm 2.50$ & $\begin{array}{l}3.00 \pm \\
7.12\end{array}$ & $0.07^{\mathrm{a}} \pm 0.11$ & $0.15 \pm 0.39$ & 18 & $\begin{array}{l}4.99 \mathrm{a} \pm \\
2.71\end{array}$ \\
\hline
\end{tabular}

Statistical analysis compares the five different cultivars in the same year (significant differences at $p<0.05$ are highlighted by different letters) and the same cultivar in two different years (significant differences at $p<0.05$ are highlighted by different symbols). nd: not detected (peak area values below 500,000 units). 


\subsection{Squalene}

Squalene is a triterpene having several beneficial properties and is found in a relatively high amount of olive oil [36]. Its content has been reported to depend markedly on the olive cultivar [37]. Thus, the present study, aiming to highlight the peculiarities of monovarietal oils, took into consideration the content of this bioactive substance, which was never investigated before in these cvs. The results (Figure 2) confirm a strong influence of variety on the squalene content found in the oils. The lowest average concentration $(0.40 \mathrm{~g} / 100 \mathrm{~g})$ was found in RAG while the highest average value $(0.92 \mathrm{~g} / 100 \mathrm{~g})$ was found in ASC. Together with MOG cultivar, it resulted in "very high content" varieties $(>0.75 \mathrm{~g} / 100 \mathrm{~g})$ when considering the classification reported by Beltran et al. [37]. The same trend was found for each cultivar in the two years and, between the two years, no significant differences have been found, which further supports a genetic reason behind the squalene concentration trend found in the MEVOOs investigated [37].

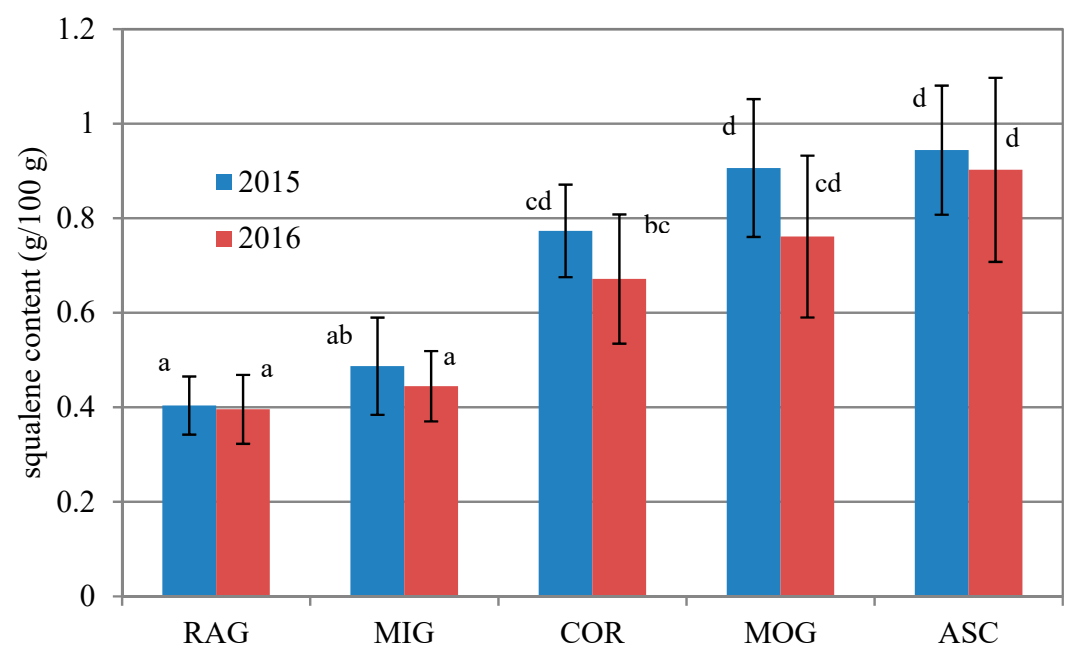

Figure 2. Average squalene content (g/100 g) in Ascolana tenera (ASC), Coroncina (COR), Mignola (MIG), Piantone di Mogliano (MOG), and Raggia (RAG) monovarietal oils investigated were produced in 2015 and 2016. Bars indicate \pm standard deviation. All different letters indicate significant differences $(p<0.05$, One-way ANOVA, Tukey's test for pairwise comparison) among the 10 oil sample groups investigated.

\subsection{Antioxidant Activity}

The total antioxidant activity was determined in the 79 MEVOOs investigated in the present study when compared to that found in industrial EVOOs purchased in local supermarkets (Table 3, Figure 3). Results do not show significant differences among the five cvs. investigated (Table 3 ). The result is in agreement with that obtained from the HPLC analysis of the polar phenolic substances and with the content of secoiridoid derivatives, which are the most abundant polar phenolic compounds of EVOOs and mainly responsible for their antioxidant properties. Furthermore, it should be considered that the antioxidant activity is given by many different substances (e.g., polar phenolic substances, tocopherols, squalene, and others) and, within the varieties investigated, some were found to be rich of one (or more) of these antioxidants and poor in others while the opposite was true for other cvs. (e.g., MOG is very rich in squalene while it contains low concentration of polar phenolic substances. RAG contains a very high amount of polar phenolic substances and a low amount of squalene, and so forth). Moreover, the different response given by the reactant to the different antioxidant substances further decreases the capability of this test of differentiating oils from different cvs.. However, the antioxidant activity shown by the whole of the MEVOOs investigated, on average $6.9 \pm 2.3$ trolox $\mu \mathrm{M}$, resulted in a significantly higher value $(p<0.05)$ as compared to that given by industrial EVOOs purchased from a large retail distribution market (on average, $5.0 \pm 0.6$ trolox $\mu \mathrm{M}$ ), which demonstrates the generally higher quality of niche MEVOOs in terms of antioxidant activity as compared to industrial EVOOs (Figure 3). 
Table 3. Results from sensory analysis (average score of each sensory attribute and average overall score) and from antioxidant activity assay (total antioxidant activity (TAA) in terms of trolox $(\mu \mathrm{M}) \pm$ standard deviation (SD) in the investigated monovarietal oils (ASC: Ascolana tenera, COR: Coroncina, MIG: Mignola, MOG: Piantone di Mogliano, RAG: Raggia) produced in 2015 and in 2016, and in the total 2015/2016 samples.

\begin{tabular}{|c|c|c|c|c|c|c|c|c|c|c|}
\hline & \multicolumn{9}{|c|}{ Sensory Analysis } & $\begin{array}{c}\text { Antioxidant } \\
\text { Activity }\end{array}$ \\
\hline & Fruity & Bitter & Pungent & Leaves/Grass & Almond & Artichoke & Tomato & Berries & Score & \multirow{2}{*}{$\begin{array}{c}\text { TAA (Average } \\
\text { Trolox } \mu \mathrm{m} \pm \mathrm{SD} \text { ) }\end{array}$} \\
\hline & \multicolumn{9}{|c|}{ Average \pm SD } & \\
\hline ASC $2015(n=6)$ & $\# 5.34^{\mathrm{a}} \pm 0.30$ & $4.76 \pm 0.41$ & ${ }^{\#} 4.67^{\mathrm{ab}} \pm 0.30$ & $\# 2.95^{\mathrm{a}} \pm 0.72$ & $1.71 \pm 1.02$ & ${ }^{\#} 2.29 \pm 0.97$ & ${ }^{\#} 2.60 \pm 0.47$ & nd & $7.76^{\mathrm{a}} \pm 0.27$ & $8.58 \pm 1.81$ \\
\hline COR $2015(n=7)$ & $\# 4.44^{\mathrm{b}} \pm 0.45$ & $4.55 \pm 0.70$ & $\# 4.65 \mathrm{ab} \pm 0.48$ & $2.37^{\mathrm{bd}} \pm 0.53$ & $2.28 \pm 0.62$ & $1.84 \pm 0.90$ & $0.27 \pm 0.72$ & $0.23 \pm 0.61$ & $7.26^{\mathrm{ab}} \pm 0.38$ & $8.10 \pm 1.74$ \\
\hline MIG $2015(n=7)$ & ${ }^{\#} 4.21^{\mathrm{b}} \pm 0.51$ & $4.16 \pm 0.52$ & $3.78^{a} \pm 0.62$ & $1.18^{\mathrm{b}} \pm 0.86$ & $\# 1.36 \pm 0.79$ & $0.57 \pm 0.73$ & nd & $1.95 \pm 1.23$ & $7.12 \mathrm{ab} \pm 0.66$ & $7.81 \pm 1.49$ \\
\hline MOG $2015(n=9)$ & $4.20^{b} \pm 0.58$ & $3.73 \pm 0.87$ & $4.05^{\mathrm{ab}} \pm 0.93$ & $2.17^{\mathrm{bd}} \pm 0.93$ & $1.82 \pm 0.92$ & $1.31 \pm 0.99$ & $0.19 \pm 0.57$ & $0.23 \pm 0.70$ & $7.06^{\mathrm{b}} \pm 0.50$ & $7.50 \pm 2.04$ \\
\hline RAG $2015(n=7)$ & $\# 4.79 \mathrm{ab} \pm 0.49$ & ${ }^{\#} 4.93 \pm 0.79$ & ${ }^{\#} 4.83^{\mathrm{b}} \pm 0.48$ & $\# 2.51$ acd \pm 0.79 & ${ }^{\#} 3.04 \pm 0.44$ & ${ }^{\#} 1.90 \pm 1.05$ & $0.21 \pm 0.54$ & nd & $\# 7.55^{\mathrm{ab}} \pm 0.27$ & $9.59 \pm 2.86$ \\
\hline ASC $2016(n=8)$ & $\S 4.06 \pm 1.16$ & $3.36 \pm 1.54$ & $\S 3.37 \pm 1.15$ & $\S_{1.47 \pm 1.50}$ & $1.21 \pm 0.98$ & $\S_{0.76 \pm 0.87}$ & $\S_{1.03 \pm 1.45}$ & nd & $7.07 \pm 0.85$ & $5.84 \pm 1.37$ \\
\hline COR $2016(n=7)$ & $\S 3.59 \pm 0.55$ & $3.76 \pm 0.94$ & $\$ 3.74 \pm 0.22$ & $1.69 \pm 1.21$ & $1.59 \pm 0.95$ & $1.29 \pm 1.21$ & $0.16 \pm 0.43$ & nd & $7.13 \pm 0.41$ & $6.20 \pm 2.33$ \\
\hline MIG $2016(n=8)$ & $\S 3.39 \pm 0.42$ & $3.66 \pm 0.88$ & $3.36 \pm 0.66$ & $0.53 \pm 0.69$ & $\S_{0.56 \pm 0.50}$ & $0.24 \pm 0.46$ & nd & $1.21 \pm 1.39$ & $7.18 \pm 0.52$ & $5.47 \pm 2.09$ \\
\hline MOG $2016(n=8)$ & $3.66 \pm 0.83$ & $3.36 \pm 1.12$ & $3.33 \pm 1.12$ & $1.25 \pm 0.83$ & $1.65 \pm 0.76$ & $1.07 \pm 1.00$ & nd & nd & $6.96 \pm 0.54$ & $6.03 \pm 1.72$ \\
\hline RAG $2016(n=12)$ & $\S 3.30 \pm 0.69$ & $\S 2.74 \pm 1.10$ & $\S 3.13 \pm 1.24$ & $\S_{0.94 \pm 0.69}$ & $\S 1.73 \pm 1.05$ & $\S_{0.71 \pm 0.70}$ & nd & nd & $\S 6.89 \pm 0.59$ & $5.40 \pm 1.94$ \\
\hline ASC $2015 / 2016(n=14)$ & $4.70 \pm 0.73$ & $4.06 \pm 0.97$ & $4.02 \pm 0.72$ & $2.10^{\mathrm{a}} \pm 1.41$ & $1.46 \pm 1.00$ & $1.53 \pm 0.92$ & $1.81 \pm 0.96$ & nd & $7.41 \pm 0.56$ & $7.02 \pm 2.06$ \\
\hline COR $2015 / 2016(n=14)$ & $4.01 \pm 0.50$ & $4.15 \pm 0.82$ & $4.19 \pm 0.35$ & $2.03^{\mathrm{a}} \pm 0.97$ & $1.94 \pm 0.78$ & $1.57 \pm 1.06$ & $0.22 \pm 0.58$ & $0.12 \pm 0.31$ & $7.19 \pm 0.39$ & $7.15 \pm 2.21$ \\
\hline MIG 2015/2016 $(n=15)$ & $3.80 \pm 0.46$ & $3.91 \pm 0.70$ & $3.57 \pm 0.64$ & $0.84^{b} \pm 0.82$ & $0.96 \pm 0.65$ & $0.40 \pm 0.59$ & nd & $0.98 \pm 0.62$ & $7.15 \pm 0.59$ & $6.56 \pm 2.14$ \\
\hline MOG $2015 / 2016(n=17)$ & $3.93 \pm 0.71$ & $3.54 \pm 1.00$ & $3.69 \pm 1.02$ & $1.74^{\mathrm{ab}} \pm 0.98$ & $1.74 \pm 0.84$ & $1.19 \pm 1.00$ & $0.09 \pm 0.28$ & $0.12 \pm 0.35$ & $7.01 \pm 0.52$ & $6.81 \pm 1.99$ \\
\hline RAG $2015 / 2016(n=19)$ & $4.05 \pm 0.59$ & $3.84 \pm 0.94$ & $3.98 \pm 0.86$ & $1.68^{\mathrm{ab}} \pm 1.08$ & $2.39 \pm 0.74$ & $1.31 \pm 0.88$ & $0.10 \pm 0.27$ & nd & $7.22 \pm 0.43$ & $6.94 \pm 3.06$ \\
\hline
\end{tabular}

For each sensory parameter, statistical analysis compares the five different cultivars with each other in the same year (2015 and 2016) and in the two years 2015/2016. Significant differences at $p<$ 0.05 are highlighted by different letters. The same cultivar is also compared in the two different years (significant differences at $p<0.05$ are highlighted by different symbols). and: not detected. 


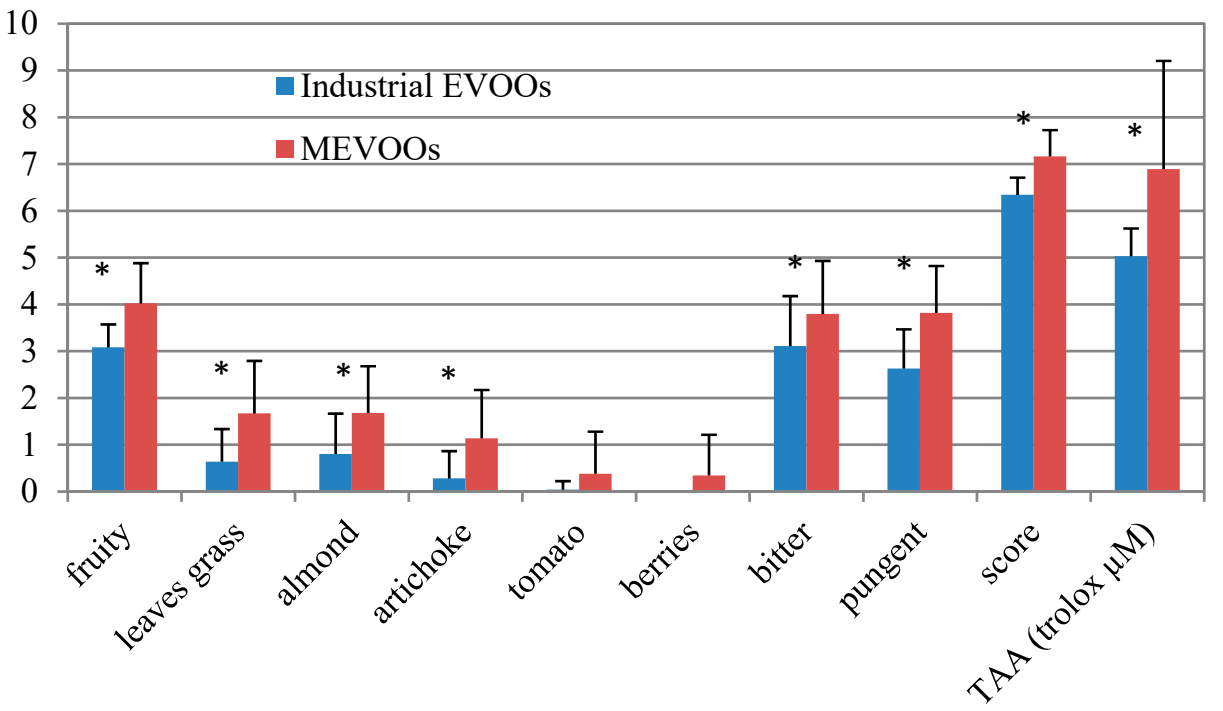

Figure 3. Comparison between the results obtained from sensory analysis and total antioxidant activity assay (TAA) of the 79 monovarietal extra virgin olive oils (MEVOOs) samples investigated (14 Ascolana tenera, 14 Coroncina, 15 Mignola, 17 Piantone di Mogliano, 19 Raggia) and 24 industrial extra virgin olive oils (EVOOs) purchased from supermarkets. Positive bars indicate standard deviation. Significant differences between Industrial EVOOs and MEVOOs are highlighted by the asterisk $(p<0.05$, One-way ANOVA and Tukey's test for a pairwise comparison).

\subsection{Sensory Analysis}

Sensory analysis was performed by an officially recognized panel, according to the procedure reported in the European Commission regulation n. 2568/91 [16] and subsequent modifications. Attributes evaluated were fruity, bitter, and pungent. However, others like e.g., the attributes of leaves/grass, artichoke/cardoon, almond, tomato, berries as well as the total score represent an indication of the overall sensory quality of the oil [25]. The oils investigated showed a generally higher level of quality in 2015 as compared to 2016 whereas, for each of the cvs. investigated, the positive attributes resulted in almost all of the cases being higher in 2015 as compared to 2016 in several cases with significant differences $(p<0.05$, Table 3$)$. This can be explained by the environmental conditions of the two years. In 2016, higher humidity and lower temperature favoured the attack of the olives by Bactrocera oleae, which resulted in a generally lower intensity of the positive sensory attributes and, thus, a generally lower quality of the oils produced as compared to 2015 oils. This finding is also in agreement with the general trend observed in Italy in these two years and reported in the national database [7]. However, independently from seasonal variations, some peculiarities of the cvs. investigated are clearly shown by the results obtained. ASC in both the years results in a cultivar with the highest average value being received for the fruity attribute, and was confirmed to be characterized by a typical note of tomato [9], highlighted in a negligible amount in the cvs.. COR presents high values for all of the attributes with the only exceptions of tomato and berries attributes resulting in peculiarity of ASC and MIG, respectively. The high score for pungency, bitterness, and artichoke/cardoon in both years is in agreement with its high relative polar phenolic substances content, which is well known to provide the oil with these sensory notes. RAG has a peculiar sensory profile. In both the years, it received the highest average score for the attributes of the almond, which can be plausibly explained with its very high content of $(E)$-2-hexenal, known to be a volatile molecule providing this sensory note. However, RAG was the variety that showed the highest variability in two years. It was the only one where all the parameters investigated (with the only exception of berries and tomato that are peculiar of specific crs.) have scores significantly lower in 2016 as compared to 2015. The peculiar attribute of berries, specifically related to MIG, correlated with the content of hexyl acetate, found to be particularly high in MIG as compared to the other crs. in both years. Hexyl acetate is a 
volatile substance recognized to provide fruity notes and previously associated with the berry note in wines [38]. A set of industrial EVOOs purchased from local supermarkets was also analysed in order to assess differences with MEVOOs investigated in the present study, which are artisanal products and generally recognized as having higher quality. A pronounced difference is found for each of the parameters considered in the sensory analysis (Figure 3). All of them resulted in significantly higher values in MEVOOs as compared to industrial EVOOs with the only exception of "tomato" and "berries" due to the fact that these attributes are specific of ASC and MIG, respectively. Thus, the results are negligible in the 79 MEVOOs investigated.

\subsection{Principal Component Analysis}

The previously discussed features have been studied by Principal Component Analysis (PCA) to highlight the relations between them, using only auto-scaled variables. Several variables show very low correlation with the most important PCs. Then, only the most important were retained: palmitic, palmitoleic, oleic, linoleic acids, $\alpha$-tocopherol, (E)-2-hexenal, acetoxypinoresinol, and squalene. PCA on the selected variables permits a raw grouping of the samples, based on the different olive cvs., as shown in Figure 4.

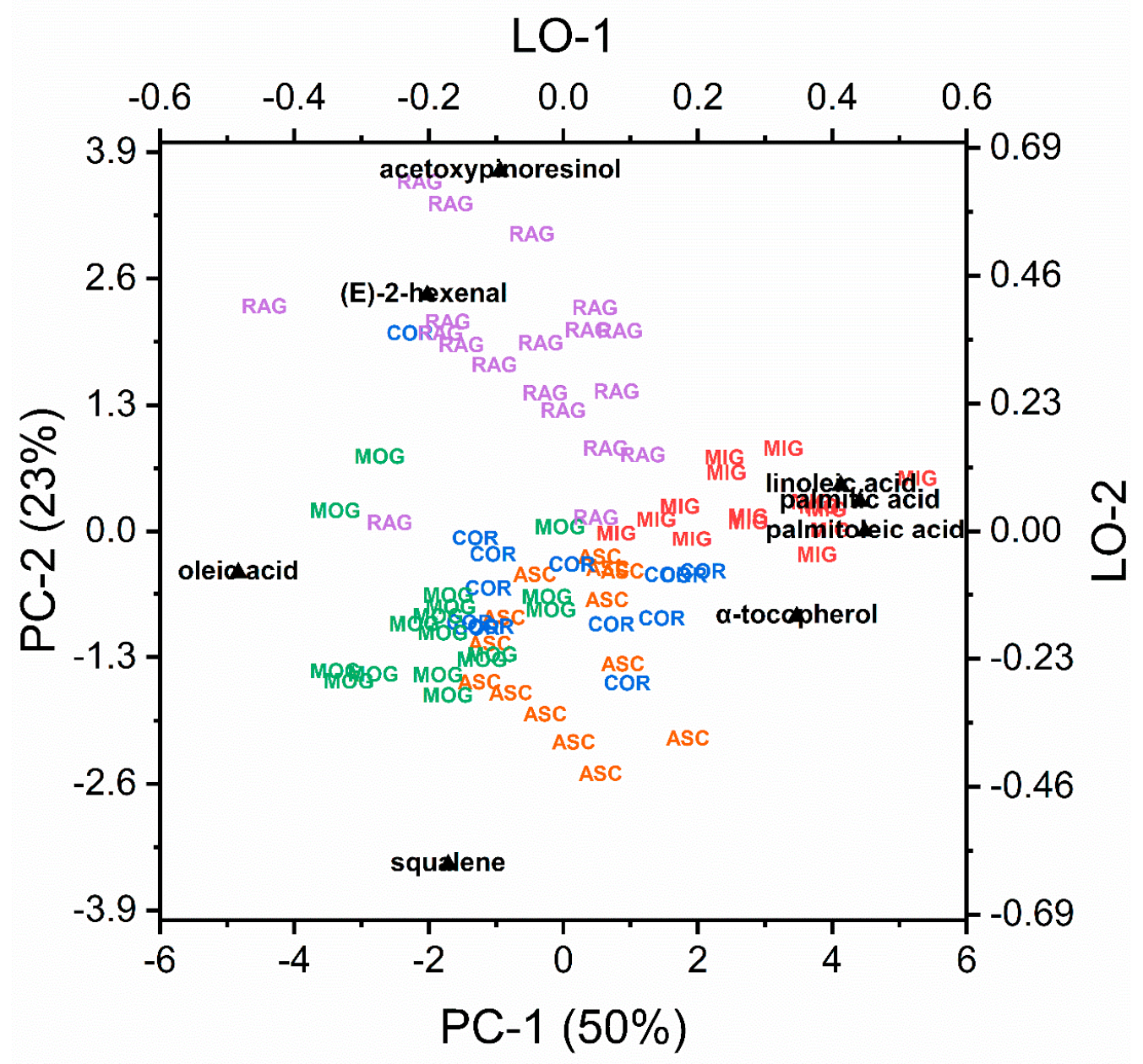

Figure 4. Biplot with projection of PC-1 vs PC-2, from PCA analysis on a subset of chemical parameters selected in order to optimize the olive cultivar separation in the monovarietal oils investigated (Ascolana tenera: ASC, Coroncina: COR, Mignola: MIG, Piantone di Mogliano: MOG, Raggia: RAG). PC: principal component, PCA: principal component analysis, LO: loading. 
This figure shows that (E)-2-hexenal, acetoxypinoresinol, and squalene divide the groups along PC-2 axis, that is, RAG and MIG from the others. Along PC-1, there is a mild separation between MIG and the others. In this direction, there are high loadings for palmitoleic, palmitic, and linoleic acids, low loading of oleic acid, and high loading of $\alpha$-tocopherol. PCA shows that few parameters, among the many investigated, are correlated with the olive cultivar. We can conclude that the analysis of the chemical parameters of the monovarietal oils analyzed permits to differentiate them, but are likely due to the relatively low number of samples the predictive ability is poor. The phenolic fraction of the analyzed parameters seems to be the most related to the varieties while the other parameters are related to quality (seasonal dependence) alone or confused with varietal differences.

\section{Conclusions}

The presented study highlights peculiar chemical features of MEVOOs produced in Marche region (Italy) and are much appreciated for their sensory properties. The study shows that, behind the sensory properties, peculiar chemical features characterize these MEVOOs, which are mostly highlighted for the first time in this study, and which point out why MEVOOs can be considered as functional foods. In most of the cases investigated here can be acknowledged with the European Food Safety Authority health claim on olive oil polar phenolic compounds, which support the healthy properties of these EVOOs. Beyond the interesting compositional features highlighted in each of the varieties studied, the MEVOOs investigated, as a whole, showed a significant difference in terms of sensory quality with respect to industrial oils. This process demonstrated their superiority both from the point of view of their antioxidant activity as well as for their sensory quality.

Author Contributions: Conceptualization, D.F. (Dennis Fiorini) and D.P.; Methodology, B.A., P.C., D.F. (Dennis Fiorini), R.G. (Rosita Gabbianelli) and M.R.; Software, P.C.; Formal Analysis, B.A., M.C.B., G.C. and D.F. (Donatella Fedeli); Data Curation, D.F. (Dennis Fiorini) and P.C.; Writing - Original Draft Preparation, P.C., D.F. (Dennis Fiorini), R.G. (Rosita Gabbianelli), D.P.; Writing - Review \& Editing, B.A., G.C., R.G. (Rita Giovannetti), R.G. (Rosita Gabbianelli) and G.S.; Supervision, M.C.B., G.C., D.F. (Donatella Fedeli), S.F., M.R., G.S.; Project Administration, D.F. (Dennis Fiorini); Funding Acquisition: D.F. (Dennis Fiorini). All authors have read and agreed to the published version of the manuscript.

Funding: The University of Camerino (Fondo di Ateneo per la Ricerca 2014-2015) financially supported this work.

Conflicts of Interest: The authors declare no conflict of interest.

\section{References}

1. Caramia, G.; Gori, A.; Valli, E.; Cerretani, L. Virgin olive oil in preventive medicine: From legend to epigenetics. Eur. J. Lipid Sci. Technol. 2012, 114, 375-388. [CrossRef]

2. $\quad$ Lopez-Miranda, J.; Perez-Jimenez, F.; Ros, E.; De Caterina, R.; Badimon, L.; Covas, M.I.; Escrich, E.; Ordovás, J.M.; Soriguer, F.; Abiá, R.; et al. Olive oil and health: Summary of the II international conference on olive oil and health consensus report, (Spain) 2008. Nutr. Metab. Cardiovasc. Dis. 2010, 20, 284-294. [CrossRef] [PubMed]

3. Carreño, I.; Vergano, P.R. Geographical indications, "Food Fraud" and the Fight Against "Italian sounding" Products. Eur. J. Risk Reg. 2016, 7, 416-420. [CrossRef]

4. Rotondi, A.; Alfei, B.; Pannelli, G.; Morrone, L.; Magli, M. Italian National Database of Monovarietal Extra Virgin Olive Oils. In The Mediterranean Genetic Code-Grapevine and Olive; Poljuha, D., Sladonja, B., Eds.; INTECH Open Access Publisher: Rijeka, Croatia, 2013; pp. 179-200. Available online: https://www.intechopen.com/books/the-mediterraneangenetic-code-grapevine-and-olive/italian-national-database-of-monovarietal-extra-virgin-olive-oils (accessed on 5 April 2020).

5. European Union. Commission implementing regulation (EU) no 29/2012 of 13 January on marketing standards for olive oil (codification). Off. J. Eur. Union 2012, L12/14.

6. Rotondi, A.; Alfei, B.; Magli, M.; Pannelli, G. Influence of genetic matrix and crop year on chemical and sensory profiles of Italian monovarietal extra-virgin olive oils. J. Sci. Food Agric. 2010, 90, 2641-2648. [CrossRef]

7. Alfei, B. Oli monovarietali. $16^{\circ}$ Rassegna Nazionale Oli Monovarietali. Olivo e Olio 2019, 3. Available online: http://www.olimonovarietali.it/repository/Catalogo\%20oli\%20monovarietali\%202019.pdf/view (accessed on 16 April 2020). 
8. ASSAM Marche and CNR-IBIMET. Banca Dati Degli Oli Monovarietali Italiani. Available online: http: //www.olimonovarietali.it/ (accessed on 4 September 2019).

9. Cecchi, T.; Alfei, B. Volatile profiles of Italian monovarietal extra virgin olive oils via HS-SPME-GC-MS: Newly identified compounds, flavors molecular markers, and terpenic profile. Food Chem. 2013, 141, 2025-2035. [CrossRef]

10. Fiori, F.; Boselli, E.; Falcone, P.M.; Balzano, M.; Frega, N.G. Effects of malaxation time on the quality of extra virgin olive oil from the ASC olive variety. Riv. Ital. Sostanze Gr. 2014, 91, 167-176.

11. Dabbou, S.; Issaoui, M.; Servili, M.; Taticchi, A.; Sifi, S.; Montedoro, G.F.; Hammami, M. Characterisation of virgin olive oils from European olive cultivars introduced in Tunisia. Eur. J. Lipid Sci. Technol. 2009, 111, 292-401. [CrossRef]

12. Caprioli, G.; Boarelli, M.C.; Ricciutelli, M.; Sagratini, G.; Fiorini, D. Micro-scaled Quantitative Method to Analyze Olive Oil Polyphenols. Food Anal. Methods 2019, 12, 1133-1139. [CrossRef]

13. Ricciutelli, M.; Marconi, S.; Boarelli, M.C.; Caprioli, G.; Sagratini, G.; Ballini, R.; Fiorini, D. Olive oil polyphenols: A quantitative method by high-performance liquid-chromatography-diode-array detection for their determination and the assessment of the related health claim. J. Chromatogr. A 2017, 1481, 53-63. [CrossRef]

14. Pacetti, D.; Scortichini, S.; Boarelli, M.C.; Fiorini, D. Simple and rapid method to analyse squalene in olive oils and extra virgin olive oils. Food Control. 2019, 102, 240-244. [CrossRef]

15. Pellegrini, N.; Visioli, F.; Buratti, S.; Brighenti, F. Direct analysis of total antioxidant activity of olive oil and studies on the influence of heating. J. Agric. Food Chem. 2001, 49, 2352-2358. [CrossRef] [PubMed]

16. European Commission. Commission regulation (EEC) no 2568/91 of 11 July 1991 on the characteristics of olive oil and olive-residue oil and on the relevant methods of analysis. Offic. J. Europ. Commun. 1991, 248, 1-83.

17. Hammer, Ø.; Harper, D.A.T.; Ryan, P.D. PAST: Paleontological statistics software package for education and data analysis. Palaeontol. Electron. 2001, 4, 1-9.

18. Cecchi, T.; Passamonti, P.; Alfei, B.; Cecchi, P. Monovarietal Extra Virgin Olive Oils from the Marche Region, Italy: Analytical and Sensory Characterization. Int. J. Food Prop. 2011, 14, 483-495. [CrossRef]

19. Alfei, B.; Fileni, L.; Santinelli, A.; Pannelli, G. Preliminari osservazioni sul comportamento produttivo delle principali varietà locali di olivo delle Marche. In Proceedings of the IV National Congress on Biodiversity, Alghero, Italy, 8-11 September 1998; pp. 253-258.

20. Lavelli, V.; Fregapane, G.; Salvador, D.M. Effect of storage on secoiridoid and tocopherol contents and antioxidant activity of monovarietal extra virgin olive oils. J. Agric. Food Chem. 2006, 54, 3002-3007. [CrossRef]

21. Chiavaro, E.; Vittadini, E.; Rodriguez-Estrada, M.T.; Cerretani, L.; Bonoli, M.; Bendini, A.; Lercker, G. Monovarietal extra virgin olive oils: Correlation between thermal properties and chemical composition. J. Agric. Food Chem. 2007, 55, 10779-10786. [CrossRef]

22. European Commission. Commission regulation (EU) no 432/2012 of 16 May 2012 establishing a list of permitted health claims made on foods, other than those referring to the reduction of disease risk and to children's development and health. Off. J. Eur. Union 2012, 136, 1-40.

23. Antonini, E.; Farina, A.; Leone, A.; Mazzara, E.; Urbani, S.; Selvaggini, R.; Servili, M.; Ninfali, P. Phenolic compounds and quality parameters of family farming versus protected designation of origin (PDO) extra-virgin olive oils. J. Food Compos. Anal. 2015, 43, 75-81. [CrossRef]

24. Caporaso, N.; Savarese, M.; Paduano, A.; Guidone, G.; De Marco, E.; Sacchi, R. Nutritional quality assessment of extra virgin olive oil from the Italian retail market: Do natural antioxidants satisfy EFSA health claims? J. Food Compos. Anal. 2015, 40, 154-162. [CrossRef]

25. Fiorini, D.; Boarelli, M.C.; Conti, P.; Alfei, B.; Caprioli, G.; Ricciutelli, M.; Sagratini, G.; Fedeli, D.; Gabbianelli, R.; Pacetti, D. Chemical and sensory differences between high price and low price extra virgin olive oils. Food Res. Int. 2018, 105, 65-75. [CrossRef] [PubMed]

26. Brenes, M.; Garcia, A.; Rios, J.J.; Garcia, P.; Garrido, A. Use of 1-acetoxypinoresinol to authenticate Picual olive oils. Int. J. Food Sci. Technol. 2002, 37, 615-625. [CrossRef]

27. Tura, D.; Gigliotti, C.; Pedo, S.; Failla, O.; Bassi, D.; Serraiocco, A. Influence of cultivar and site of cultivation on levels of lipophilic and hydrophilic antioxidants in virgin olive oils (Olea Europea L) and correlations with oxidative stability. Sci. Hortic. 2007, 112, 108-119. [CrossRef]

28. Aguilera, M.P.; Beltrán, G.; Ortega, D.; Fernández, A.; Jiménez, A.; Uceda, M. Characterisation of virgin olive oil of Italian olive cultivars: 'Frantoio' and 'Leccino', grown in Andalusia. Food Chem. 2005, 89, 387-391. [CrossRef] 
29. Haddada, F.M.; Krichène, D.; Manai, H.; Oueslati, I.; Daoud, D.; Zarrouk, M. Analytical evaluation of six virgin olive oils from Northern Tunisia. Eur. J. Lipid Sci. Technol. 2008, 110, 905-913. [CrossRef]

30. Morales, M.T.; Rios, J.J.; Aparicio, R. Changes in the volatile composition of virgin olive oil during oxidation: Flavors and off-flavors. J. Agric. Food Chem. 1997, 45, 2666-2673. [CrossRef]

31. Angerosa, F.; Camera, L.; D’Alessandro, N.; Mellerio, G. Characterization of Seven New Hydrocarbon Compounds Present in the Aroma of Virgin Olive Oils. J. Agric. Food Chem. 1998, 46, 648-653. [CrossRef]

32. Alfonso, I.; Vacas, S.; Primo, J. Role of $\alpha$-copaene in the susceptibility of olive fruits to Bactrocera oleae (Rossi). J. Agric. Food Chem. 2014, 62, 11976-11979. [CrossRef]

33. Gómez-Coca, R.B.; Cruz-Hidalgo, R.; Fernandes, G.D.; Pérez-Camino, M.D.C.; Moreda, W. Analysis of methanol and ethanol in virgin olive oil. MethodsX 2014, 1, 207-211.

34. Biedermann, M.; Bongartz, A.; Mariani, C.; Grob, K. Fatty acid methyl and ethyl esters as well as wax esters for evaluating the quality of olive oils. Eur. Food Res Technol. 2008, 288, 65-74. [CrossRef]

35. Mariani, C.; Bellan, G. Sul possibile aumento degli alchil esteri negli oli extravergini di oliva. Riv. Ital. Sostanze Gr. 2001, 88, 3-10.

36. Lou-Bonafonte, J.M.; Martínez-Beamonte, R.; Sanclemente, T.; Surra, J.C.; Herrera Marcos, L.V.; Sanchez-Marco, J.; Arnal, C.; Osada, J. Current insights into the biological action of squalene. Mol. Nutr. Food Res. 2018, 62, 1800136. [CrossRef] [PubMed]

37. Beltran, G.; Bucheli, M.E.; Aguilera, M.P.; Belaj, A.; Jimenez, A. Squalene in virgin olive oil: Screening of variability in olive cultivars. Eur. J. Lipid Sci. Technol. 2016, 118, 1250-1253. [CrossRef]

38. Forde, C.N.G.; Cox, A.; Williams, E.R.; Boss, P.K. Associations between the sensory attributes and volatile composition of Cabernet Sauvignon wines and the volatile composition of the grapes used for their production. J. Agric. Food Chem. 2011, 59, 2573-2583. [CrossRef] [PubMed]

(C) 2020 by the authors. Licensee MDPI, Basel, Switzerland. This article is an open access article distributed under the terms and conditions of the Creative Commons Attribution (CC BY) license (http://creativecommons.org/licenses/by/4.0/). 